\title{
Relationships between Recreational User Perceptions and the Biological Condition of West Virginia Watersheds
}

Jennie M. Franks

West Virginia University

Follow this and additional works at: https://researchrepository.wvu.edu/etd

\section{Recommended Citation}

Franks, Jennie M., "Relationships between Recreational User Perceptions and the Biological Condition of West Virginia Watersheds" (2013). Graduate Theses, Dissertations, and Problem Reports. 560.

https://researchrepository.wvu.edu/etd/560

This Thesis is protected by copyright and/or related rights. It has been brought to you by the The Research Repository @ WVU with permission from the rights-holder(s). You are free to use this Thesis in any way that is permitted by the copyright and related rights legislation that applies to your use. For other uses you must obtain permission from the rights-holder(s) directly, unless additional rights are indicated by a Creative Commons license in the record and/ or on the work itself. This Thesis has been accepted for inclusion in WVU Graduate Theses, Dissertations, and Problem Reports collection by an authorized administrator of The Research Repository @ WVU. For more information, please contact researchrepository@mail.wvu.edu. 


\title{
Relationships between Recreational User Perceptions and the Biological Condition of West Virginia Watersheds
}

\author{
Jennie M. Franks \\ A thesis submitted \\ to The Davis College of Agriculture, Natural Resources, and Design \\ at West Virginia University \\ in partial fulfillment of the requirements \\ for the degree of \\ Master of Science in \\ Wildlife and Fisheries Resources
}

J. Todd Petty, Ph.D., Chair

Patricia M. Mazik, Ph.D.

Robert C. Burns, Ph.D.

Department of Wildlife and Fisheries

Morgantown, West Virginia

2013

Keywords: bioassessment, water recreation, perceptions, watershed management Copyright 2013 Jennie Franks 
ABSTRACT

\section{Relationships between Recreational User Perceptions and the Biological Condition of West Virginia Watersheds}

Jennie M. Franks

Limitations in bioassessments of stream condition should be recognized and a need exists to broaden our approach to identify and solve knowledge gaps in scientific data. Combining collection methods based upon biological data and social perceptions may provide an effective way to identify gaps and involve local stakeholders in river conservation strategies. Our research objectives were to: 1- describe recreational users and their perceptions of water quality; 2- quantify relationships between recreational user perceptions and biological condition; 3- examine if perceptions vary spatially across watersheds; and 4- determine if recreational users' values and perceptions can be used to complement bioassessment surveys of West Virginia rivers. A web-based user perception survey was conducted between the months of May and September, 2012. We used a snowball sampling technique that targeted watershed organizations and water recreation outfitters as initial contacts. Fishery data from 2000-2010 was used from eleven HUC8 watersheds as bioindicators of river condition. River segments and perceptions were compared to each other to classify rivers of high and low perceived quality. Due to small sample size a statistically significant relationship could not be determined between user perceptions and biological condition, however interpretable patterns did occur based on mean perception ratings. Half of the surveyed wadeable stream segments were in agreement among ranked perceived swim quality and ranked total intolerant benthic species richness, percent intolerant species and percent invertivore/piscivore. Additionally, only six river segments were in agreement for both boating and fishing quality compared to species richness and conservative game abundance. Water recreationists can be used to incorporate stakeholder support and their perceptions can be used to detect knowledge gaps between perceived and actual river conditions. 


\section{ACKNOWLEDGEMENTS}

First and foremost, I would like to thank Dr. Kris Wright and Dr. R.J. Rowley for their constant support and encouragement during my journey into graduate school. Without their guidance, friendship, and confidence in my potential, none of this would have been possible. To Kris, you have advised me and given me the opportunity to find my passion for a career in natural resources and for that I am forever grateful.

Thanks to the Peace Corps Masters International program for this amazing experience as I continue to grow personally and professionally. I feel honored to be representing West Virginia University during my time of service in Jamaica. Special thanks to my graduate advisor and mentor, Dr. Todd Petty for this opportunity. During my time at WVU you have never once doubted my ability and have entrusted me with challenging tasks and responsibility. I am thankful for all of your insight, theory discussions, conceptual graphs, and professional advice. Thank you to my committee members, Dr. Robert Burns and Dr. Pat Mazik, your advice, enthusiasm, and support were crucial to my academic achievements.

I am indebted to all my fellow graduate students for their consistent help, advice, friendship, and continued support. An enormous thanks to Catherine Artis and Milu Karp, graduate school would not have been the same without you. Last but not least, I would like to thank Bobby Burken for being there and always pushing me to continue and experience the world. All aspects of where I am today can be attributed to his friendship, honesty, and support. 


\section{TABLE OF CONTENTS}

ABSTRACT

ACKNOWLEDGEMENTS

Page

TABLE OF CONTENTS

LIST OF TABLES

LIST OF FIGURES

CHAPTER ONE: INTRODUCTION

Introduction

Objectives 3

CHAPTER TWO: LITERATURE REVIEW $\quad 4$

Implementation of the Clean Water Act 4

West Virginia Biomonitoring Assessment 6

Knowledge Gaps in Bioassessments 9

Integrating Local and Scientific Knowledge 10

Recreational User Perceptions \& Measured Condition 13

CHAPTER 3: METHODOLOGY 16

Study Area $\quad 16$

Fishery dataset $\quad 19$

Survey Implementation $\quad 21$

$\begin{array}{ll}\text { Survey Instrumentation } & 24\end{array}$

Limitations \& Delimitations $\quad 30$

Statistical Analysis 33

Recreational User Perceptions of West Virginia 33

Relationships between Perceptions and Biological condition $\quad 34$

Spatial Patterns of User Perceptions 36

CHAPTER 4: RESULTS $\quad 37$

Recreational User Perceptions of West Virginia $\quad 37$

Relationships between Perceptions and Biological Condition 50

Spatial Patterns of User Perceptions $\quad 62$

$\begin{array}{ll}\text { CHAPTER 5: DISCUSSION } & 63\end{array}$

Recreational User Perceptions of West Virginia 63

Relationships between Perceptions and Biological Condition 73

Spatial Patterns of User Perceptions $\quad 77$

$\begin{array}{ll}\text { Summary and Conclusions } & 78\end{array}$

Management Implications $\quad 81$

Future Work $\quad 82$

References $\quad 84$

Appendix A: Conservative Game Abundance $\quad 92$

Appendix B: Survey Instrument 93 


\section{LIST OF TABLES}

Table Title $\quad$ Page

1 Surveyed River Segments and Watersheds Grouped by Major Basin 18

$2 \quad$ Fish Metrics Calculated for Each Fish Sampling Event 21

3 Abbreviated Survey Questions with Source, Scale and Measure 26

$4 \quad$ Total Survey Responses by Watershed 37

5 Demographic Variables Compared Between Watersheds 38

6 Travel Distance by Watershed 39

$7 \quad$ Targeted Fish Species $\quad 42$

$8 \quad$ Number of Recent Anglers by Fish Category and by Watershed 43

9 Demographic Summary Statistics of the Study Area 44

10 Activity Participation by Watershed 46

11 ANOVA Table Comparing Perception by Activity Type 50

12 Impaired and Non-Impaired Surveyed River Segments $\quad 54$

13 River Segment and Total Number of Impairment Sources 55 


\section{LIST OF FIGURES}

Figure Title $\quad$ Page

$1 \quad$ Overview Map of the Study Area $\quad 17$

2 Fish Sampling Events Corresponding to the Surveyed River Segments 20

3 Conceptual Diagram of Composited Perception Ratings 35

$4 \quad$ Mean and Standard Deviation of Fish Caught in a Given Trip by Watershed 40

$5 \quad$ Distributions of Activities Ranked Against Perception by Watershed 48

6 Ranked Conservative Game Abundance Compared to Perceived Quality by 52 Large River and Wadeable River Segments

$7 \quad$ River Segments by Impairment Source 56

$8 \quad$ Suitability and Water Quality Perception by Impairment Source 57

$9 \quad$ Perception of Suitability by Activity Grouped by Impaired and Non-Impaired 59 River Segments

10 Perceived Water Quality by Activity Grouped by Impaired and Non-Impaired 61 River Segments 


\section{CHAPTER ONE \\ INTRODUCTION}

Understanding the physical, chemical, and biological processes of rivers and streams will forever remain incomplete due to time and cost constraints of sampling as well as constant environmental change to these systems. Numerous data collection and reporting techniques have been developed, but fishery biologists have been known to be unwilling to adapt to one standard method (Bonar \& Hubert, 2002). Gear type, sampling period, length of sample, collector, and organization methods are just a few variables in which scientific data can differ and incorporate bias on a small scale making it difficult to compare water bodies. The limits of bioassessments should be recognized in terms of precision and uncertainty. A need exists for additional inputs into decision making and a more succinct priority setting technique concentrating on multiple resource demands (Doremus, 2006).

There has been an emerging consensus for the need to broaden approaches to environmental solutions by incorporating societal perspectives (Berkes et al., 2003). It's become crucial for water resource managers to close the gap between the scientific and applied sources of knowledge in reducing uncertainty by co-managing and building a complete understanding of the river landscape. Local knowledge can help fill data gaps where scientific assessments have either failed or cannot consider, given the difficulty in incorporating complex social systems (Tobias, 2000; Hall \& Close, 2007).

The significance of incorporating human dimensions in fisheries management has been studied and emphasized. Unfortunately, barriers remain in the use of non-scientific knowledge in river condition assessments. Local stakeholders and active resource users are often 
overlooked and their detailed knowledge of the land, land use practices, and adjacent watersheds are ignored (Johnson et al., 2002). Literature suggests that the most effective approaches to protect and restore water quality integrate three main elements: problem identification, stakeholder involvement, and integrated actions (Cline \& Collins, 2003).

Social impact assessments (SIAs) are the main requirement in federal fishery management plans used to incorporate human dimension information. SIAs mostly consist of census data and include potential effects on culture, community, political systems, environment, health, and personal values (Hall-Arber et al., 2009). SIAs estimate future regulatory change needed to minimize social impacts while achieving conservation goals. Unfortunately the listed impacts are rarely analyzed or implemented (Hall-Arber et al., 2009). Chambers (1980) acknowledged "The most difficult thing for an educated expert to accept is that poor farmers may often understand their situations better than he does......It is difficult for some professions to accept that they have anything to learn from rural people, or to recognize that there is a parallel system of knowledge to their own which is complementary, that is usually valid and in some aspects superior".

With the implementation of a user perception survey, watershed planning can embrace public participation and has the ability to contribute valuable information regarding the state of a water body (Duram \& Brown, 1999). Local improvements can be prioritized by comparing locations within watersheds to each other (Stringfellow, 2008). By combining methods based upon bioassessments and social perceptions, it can provide a promising way to involve local 
stakeholders in conservation strategies aimed to educate, improve, and restore rivers and streams within the state of West Virginia.

\section{Objectives}

The overriding goal of this study was to determine if recreational users' values and perceptions can help minimize knowledge gaps within bioassessments of West Virginia waters. The specific objectives for this study were to: 1). Explore and describe recreational user perceptions of water quality in West Virginia, 2). Define relationships between perceptions and biological condition on a river segment and HUC8 watershed level, 3). Describe spatial patterns of user perceptions across the study area, and 4). Determine the utility of perception data within the context of watershed management. 


\section{CHAPTER TWO \\ LITERATURE REVIEW}

Implementation of the Clean Water Act

Since the establishment of the Clean Water Act (CWA) significant progress in restoring and maintaining the biological integrity of the nation's waters has been made. The United States Congress first recognized the value of our nation's waters in 1948 with the passage of the Federal Pollution Control Act (formally known as the Clean Water Act), 62 Stat. 1155, 33 U.S.C. $\S \S 466$ to $466 \mathrm{~g}$. The Act provided a foundation for water pollution control and encouraged states to enforce pollution with water quality standards. The Act expanded significantly in 1972 when it became the Clean Water Act providing amendments focused specifically on three major pollution control mechanisms: (1) control of industrial and municipal discharges; (2) control of oil and hazardous materials spills; and (3) funding for construction of sewage treatment facilities (Goplerud III, 1995). The 1972 amendments concentrated on setting water quality standards and effluent restrictions. Since 1972, the CWA has been modified in 1977 (P.L. 95-217), 1981 (P.L. 97-117), and 1987 (P.L. 100-4) (Goplerud III, 1995).

The CWA has done its part by improving the nation's waters; however miles of rivers and streams continue to be considered impaired for one or more designated uses (Copeland, 2006). Within the 1972 amendment (P.L. 92-500), the goal was for all waters of the United States to be fishable and swimmable by 1983 and to have no discharge of pollutants by 1985 (Goplerud III, 1995). The goal became too ambitious for the improvement of water quality. The complexity of restoring and maintaining the chemical, physical, and biotic integrity of the nation's waters would need a systematic and scientific approach to improve water quality. 
Under section 402 of the CWA, the National Pollution Discharge Elimination System (NPDES) was created to prohibit the discharge of pollutants from any point source into the nation's waters with the exception of a NPDES permit. This program allowed the Environmental Protection Agency (EPA), states and industry to limit the amount of effluent from entering into any navigable body of water. The undertaking has since expanded from regulating point source through NPDES permits to non-point source pollutants under section 303(d) of the CWA and TMDL (total maximum daily load) development. The latter has been the driving force behind current U.S. water quality policy (Muñoz-Carpena et al., 2006).

The top-down regulatory approach used with point source water pollution proved to be less effective in reducing non-point source pollution (NPS) because of its source properties (Hu 2011). USEPA's initial guidelines for developing TMDL's in response to 303(d) listed waters were vague and have caused confusion among state agencies with specific assessment and listing criteria (Keller \&Cavallaro, 2008). Section 303(d) requires states to identify water segments that do not meet water quality standards (WOS) and requires states to develop TMDLs for each impaired segment. Those waters not meeting water quality standards for a designated use are considered impaired and requires a TMDL. Each TMDL sets the maximum threshold of a pollutant a waterbody can receive without violating water quality standards. After TMDLs are determined for each impaired segment, there is no EPA guidance thereafter of how to proceed toward the improvement of water quality. The actual attainment of acceptable levels per pollutant is not required (Benham et al., 2007). If a state fails to develop TMDLs for each impaired waterbody listed, EPA is required to develop a priority list for that state and will determine the TMDLs. In West Virginia, TMDLs were developed by EPA Region III from 1997- 
2003 as a result of a 1995 lawsuit (Ohio Valley Environmental Coalition, Inc., West Virginia Highlands Conservancy et al. v. Browner et al.) (WVDEP, 2010).

\section{West Virginia Biomonitoring Assessment}

The mid-Atlantic region has the lowest annual average rainfall $\mathrm{pH}$ in the United States, and the second highest acid rain accumulation in the world. Also, this region is heavily impacted by acid mine drainage from pre-law coal mines (Collins et al., 2005; Stoddard et al., 2006; USEPA, 2011). The West Virginia Department of Environmental Protection (DEP) in 2010 determined that approximately one-third $(10,758 \mathrm{~km})$ of West Virginia's streams are impaired (WVDEP, 2010). The most common causes of biological impairment as determined by the West Virginia Stream Condition Index (WVSCl) are bacterial contamination and mine drainage.

Currently the WVDEP's Division of Water and Waste Management (DWWM) collects the majority of the state's surface water quality data on a 5-year rotating basin schedule. The DWWM follows a tiered approach collecting data from long-term sampling stations, targeted sites, randomly selected sites, and sites selected for further defining impaired segments for TMDL development (WVDEP, 2010). In conducting surface water monitoring, the WVDEP established a Biological Assessment Program (BAP) designed after the Rapid Bioassessment Protocols (RBP) of the EPA (Plafkin et al., 1989; EPA, 2000; Yagow, 2006). Bioassessment refers to the analysis of sampling and classifying biological communities surrounding the stream ecosystem (Yagow, 2006). Common bioassessments document an assortment of metrics that are ideally tied to human influences that can be used to assess species richness/abundance, composition, pollution tolerance, and trophic/behavioral characteristics. Identified metrics are 
typically compiled into a single index. The index score is compared to a reference stream that expresses the highest biological potential for a particular region.

Typically, there are three common biological assemblages used in bioassessment programs: algae, macroinvertebrates and fishes (Yagow et al., 2006). Algae assessments include diatoms, blue-green, and green algae. Algae responds quickly to environmental change, causes minimal disturbance when sampling, and does not significantly differ among watersheds or streams of different sizes. The USEPA recommends using algae in bioassessments as a supplement to other biological community data because of algal dependence on natural cycles, sunlight and their instability during high flow. USEPA guideline documents recommend fish and macroinvertebrate assemblages to be applied in state water evaluation programs (Walters, 2006). Macroinvertebrate assessments are most commonly used. However, studies have found that assessing only one community type may be less effective in differentiating between attainment and nonattainment of stream designated uses (Yagow et al., 2006). If a stream exceeds the minimum threshold of its water quality standards it is considered to be in attainment for one or more of its designated uses. Contrastingly, if a stream is in nonattainment, it is not meeting its water quality standards and therefore requires a TMDL for a particular pollutant. Designated uses includes public water supply, protection and propagation of fish, shellfish, and wildlife, recreation, consumption of fish and shellfish by humans, agricultural, and industrial uses.

West Virginia uses a Stream Condition Index (SCI) composed of six metrics represented by benthic macroinvertebrates on a family level (USEPA, 2000; WVDEP, 2010). WVSCI was 
developed in 2000 to identify streams with known impairments from reference streams. A genus level index called the Genus Level Index of Most Probable Stream Status (GLIMPSS) is now being used by the WVDEP which is stratified by season and ecoregion (WVDEP, 2012). The GLIMPSS index is calculated the same as WVSCI into a single index value and then compared to reference streams within similar geographic locations. Invertebrates are good indicators of water quality and assessments can be used to determine if waterways are meeting their water quality standards (Yagow et al.; 2006).

Fish assessment programs that have been previously applied in West Virginia include: EMAP (Environmental Monitoring and Assessment Program), EMAP-MAHA (Environmental Monitoring and Assessment Program- Mid-Atlantic Highlands Assessment), and REMAP (Regional Environmental Monitoring and Assessment Program). Fishes represent effective bioindicators due to their diverse morphological, ecological, and behavioral adaptations to the natural environment (Karr, 1986; McCormick et al., 2001; Walters, 2006). Fishes are relatively easy to identify, occupy all positions within aquatic environments, and are valuable economically and socially. West Virginia University is currently working with state and federal agencies to develop a fish IBI on the state level (A. Anderson, unpublished data).

EMAP followed a probabilistic survey design where the sites were randomly selected to predict the probability of a condition occurring within a watershed. Sampled streams were treated as a continuous surface to estimate the percent of stream miles considered impaired with a known level of confidence (Detenbeck \& Cincotta, 2008). EMAP's streams were based on reference streams identified by watershed land use, indicators of human disturbance, 
habitat, and water quality data (McCormick et al., 2001). EMAP did not take into consideration any eco-regional differences. REMAP was developed to incorporate ecoregions and the potential influence of different thermal regimes (Detenbeck \& Cincotta, 2008). Effort in research and sampling design continues to improve surface water monitoring and aids in the determination of use attainment status.

Numerous remediation projects have been applied for acid mine drainage, agriculture, and stream bank erosion as a result of WVDEP's nonpoint source control program with support from agency stakeholders (federal, state, and local government) (WVDEP, 2010). As budgets are sequestered, West Virginia needs to prioritize and justify which stream segments should be restored. The Office of Surface Mining (OSM) estimates a minimum amount of $\$ 3.8$ billion to treat all sites affected by acid mine drainage alone (USEPA, 2011). The 2010 plan stresses an additional need for "more resources on voluntary installation of best management practices in identified priority watersheds where local stakeholders are interested in making a difference" (WVDEP, 2010, p. 32). Stakeholders as an entity should be used in determining which stream locations deserve priority attention (Stringfellow, 2008). The majority of West Virginia's waterways are affected by nonpoint source pollutants where stakeholder engagement becomes crucial especially on privately owned lands (Benham et al., 2007).

\section{Knowledge Gaps in Bioassessments}

Biological data are collected by multiple sources statewide including but not limited to academia, non-governmental organizations, state and federal agencies. Each entity collects and stores the data differently making it difficult for all data to be compiled into one single 
database. Some data sets are likely to still be in a hard copy format or have been lost. Time and money are spent annually on biomonitoring assessments but there is no protocol describing how to manage and organize the data (Halvorson, 2005). Excess amounts of data are being collected every year without a way to assess accuracy or quality thus creating data gaps. Gaps are generated by various sampling efforts, lack of communication, incorrect management applications (i.e. data divergence from management objectives), and inaccurate coordination among collectors (Halborson, 2005; Doremus, 2006).

Doremus (2006) refers to the scientific information gap as a supply pipeline in which scientific data is an input to regulatory decisions. Steps addressed in the pipeline are exploration, extraction, refining, blending, distribution, and consumption; any holes in the pipeline creates information gaps. Biological information is constantly needed and it is impossible to sample every location regularly. In identifying current knowledge gaps managers can understand areas in need of priority information. Combining local ecological knowledge with conventional bioassessment data can potentially provide a means by which we may bridge some gaps in our knowledge.

Integrating Local and Scientific Knowledge

Socio-demographic information on outdoor recreation is collected on state and national scales periodically. The National Survey on Recreation and the Environment (NRSE) is a continuation of the National Recreation Survey (NRS) series that began in 1960 by the Outdoor Recreation Resources Review Commission (ORRRC). The original survey was a four season, inhome survey of outdoor participation within the United States. Since 1960 the survey has been 
conducted in 1965, 1970, 1972, 1977, 1982-1983, 1994-1995, 2000-2002, and 2005-2009

(Hoyle, 2009). The survey encompasses recreation activity, environmental attitudes, and natural resource values (Hoyle, 2009). In West Virginia socio-demographic information as it relates to outdoor recreation is documented within SCORP, the Statewide Comprehensive Outdoor Recreation Plan. This plan allows funding to procure through the Land and Water Conservation Fund (LWCF) to develop public outdoor recreational areas within the state (WV Commerce, 2013). The plan provides demographics as is relates to swimming, fish/hunt, camp/canoe, and boating activities. It does not include any environmental attitudes or perceptions.

Protection of public health was formerly the main reason to regulate and focus towards the perception of water quality (David, 1971; Nicolson \& Mace, 1975; West, 1989). With increasing stress on resource managers to justify and quantify human conflicts over water, there has been an increase in correspondence among scientists, environmental managers, and the general public between environmental indicators and socio- economic indicators (Niemi \& McDonald, 2004). Human interactions strongly influence how our landscapes are managed and policies are often governed by perceived, rather than conveyed, knowledge (Brown et al., 2004).

Scientific assessments and perceived values both have disadvantages and advantages. Bioassessments can be limited by condensing information (e.g., IBI tools) and focusing on specific concerns rather than viewing the entire system. Using an assessment tool such as the IBI can often lose context of the overall ecosystem. Scientific assessments are objective, but in 
areas where data is inaccurate or missing, local knowledge can provide a starting point in identifying where information gaps occur. Recreationists, such as anglers, who regularly have contact with rivers and streams possess a broader system-wide knowledge base. However, this local knowledge may be convoluted by past experience and considered biased or subjective. Nevertheless, local values provide three advantages over scientific data: it supplies information on the local environment and its processes, it contributes direct experience with local ecology, and local people know how to use available natural resources at their disposal efficiently (DeWalt, 1994; Brown et al., 2004).

David (1971) and Nicolson \& Mace (1975) postulated the idea of user perceptions being an important supplement to existing water quality measures that could help to implement effective management procedures to control and improve water quality. Nicolson \& Mace (1975) expressed a need for more information on user perceptions and a knowledge of water quality to identify existing relationships between changes in water recreation use and demand. They concluded that public understanding of water quality can be useful in defining the relative importance of metrics that are currently being used to measure water quality. They suggest that the definition of water pollution can be revised to integrate both recreation and scientific perspectives.

A report by the Environmental Studies Board of the National Academy of SciencesNational Academy of Engineering (NAS-NAE) in 1975 noted an approach to improve our understanding of land use and other environmental areas by measuring people's perceptions of environmental quality. A true comprehensive assessment of environmental quality includes the 
quality of the experienced environment in which observer-based evaluations can complement biological indices (Craik \& Zube, 1976). The NAS-NAE 1975 report initiated the concept of perceived environmental quality indices (PEQI) and urged the science community to develop standard PEQIs (Craik \& Zube, 1976). Unfortunately, in order to be useful within a management or policy context, perceived environmental indicators must be reliable and free of systematic bias (Hyman, 1981). When asking for personal opinions, wide variations result making it difficult in establishing a standard measure of perceived quality for large populations. The user population perceives not only the rivers' most current conditions but memories and past experiences making it difficult in creating a procedural approach which is objective and practical.

Water Recreational User Perceptions and Measured Condition

Studies comparing user perceptions to measured water quality started appearing in the scientific literature within the 1990s (Smith et al., 1995). Perceptions of those participating in swimming (Smith et al., 1991; Smith \& Davies-Colley, 1992; Smith et al., 1995; Suplee et al., 2009), fishing (Neis et al,. 1998; Mackinson \& Nøttestad, 1998; Mackinson, 2001; Rochet et al., 2008), and boating (Lipton, 2004) activities have been studied, but there are no known studies that have looked at perceptions across all three water recreation types as it relates to water quality.

Perceived water appearance (clarity and color) has been compared by using secchi disk techniques for clarity, a Farnsworth-Munsell 100-Hue Test for color (Smith et al., 1995), and algae levels using chlorophyll a (Suplee et al., 2009). Smith et al. (1995) found water 
appearance and bathing activity to be closely correlated $(r=0.92)$. Water color was the dominate variable over clarity in perceiving water appearance. For bathing waters it was found that overall site suitability was strongly related to the perception of visual clarity, but less strongly related to actual clarity measured by secchi disk readings. In addition to water appearance, presence of waste contaminants in the water column and solid litter at water's edge also had an impact on recreational value (Dinius, 1981). The presence of algae has also been shown to interfere with recreation activity (fishing-snags \& lures, swimming-slippery \& dangerous, boating-tangled paddles) (Suplee et al., 2009). Site appearance has more of an effect on recreation use than actual water quality.

Associations between fishermen observations and traditional scientific data have been used to cross validate stock density, gear efficiency, and CPUE (catch per unit effort) data (Neis et al., 1999). Fishermen tend to develop a detailed understanding of fish populations on a small scale and local information can be used in quantitative stock assessments. Combining local and scientific knowledge can account for greater acceptability in fisheries science, and stakeholders are directly contributing to the management of aquatic resources (Mackinson \& N $\varnothing$ ttestad, 1998). Regardless of biased perceptions, fishermen tend to observe environmental degradation, habitat preferences, fish abundance dynamics, current water regime fluctuations, and local assemblage structure.

Fishermen perceptions were found to be very important to fishery management particularly on a short time-frame more than scientific monitoring. Rochet et al. (2008) found fishermen were capable of detecting detrimental changes more quickly than a timely scientific 
assessment. Resource users are sensitive to dramatic changes especially with increased contact to the resource. Perceptions of biological condition and user knowledge can be used in identifying boom-bust fisheries and disastrous regime shifts on short time frames and faster than any scientific assessment could acquire the appropriate data (Rochet et al. (2008).

Boat recreation has not generally been studied in terms of river water quality perception (Lipton, 2004). A pilot study was conducted on Chesapeake Bay boaters to determine the value of water quality improvements. Lipton (2004) found that water quality did impact boating recreation. In situations where water quality was poor, boaters were more willing to pay to see an improvement. There are no known studies comparing more than one type of water recreation to perceived quality across locations. Comparing perceptions and activity types of different streams to each other may have the ability to prioritize management actions within political boundaries and provide insight into where the gaps in knowledge are occurring. 
CHAPTER THREE

METHODOLOGY

The objectives for this study were to: 1). Explore and describe recreational user perceptions of water quality in West Virginia, 2). Define relationships between perceptions and biological condition on a river segment and HUC8 watershed level, 3). Describe spatial patterns of user perceptions across the study area, and 4). Determine the utility of perception data within the context of watershed management.

\section{Study Area}

Survey data were collected on a watershed hydrological unit code of 8 (HUC8) within the state of West Virginia (Figure 1). Thirteen watersheds were selected based upon available fishery data, drainage area, and location within the state (Table 1). Within each watershed, three to six river segments were chosen to best represent each HUC8 watershed. River segments were selected by expert opinion and recreation popularity. Expert opinion is defined as opinion acquired by Dr. Todd Petty, Professor of Wildlife and Fisheries at West Virginia University. He is most familiar with the fishery data that were collected and has experience with the selected river segments. A total of 47 river segments were used in representing the 13 HUC8 watersheds. Due to extremely low survey response rates $(n=3)$, the Tug and Upper Guyandotte watersheds were not included in our final analysis resulting in a final sample size of 41 river segments and 11 HUC8 watersheds. 


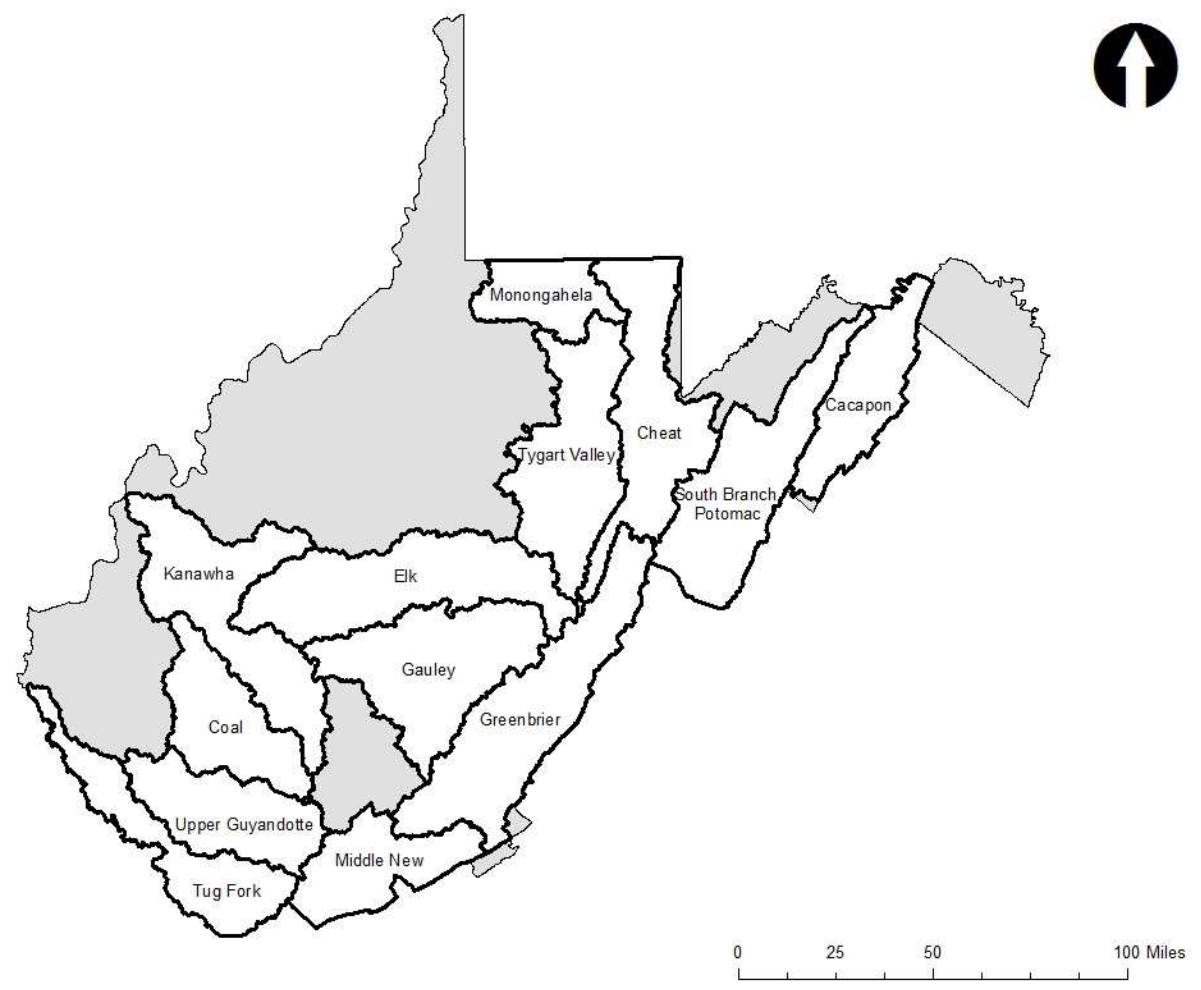

Figure 1. Overview map of the thirteen HUC8 watersheds surveyed. 
Table 1. Surveyed watersheds and their corresponding river segments grouped by major basin.

\begin{tabular}{|c|c|c|c|c|c|}
\hline Major Basin & $\begin{array}{c}\text { HUC8 } \\
\text { Watershed }\end{array}$ & River Segment & $\begin{array}{l}\text { Major } \\
\text { Basin }\end{array}$ & HUC8 Watershed & River Segment \\
\hline \multirow{3}{*}{ 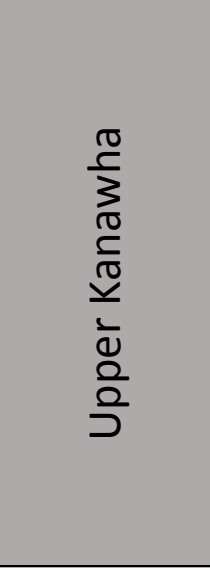 } & Middle New & $\begin{array}{l}\text { New River } \\
\text { Lower Bluestone } \\
\text { Indian Creek }\end{array}$ & \multirow{2}{*}{$\begin{array}{l}\text { U } \\
\stackrel{\sigma}{E} \\
\stackrel{0}{0} \\
\stackrel{0}{0}\end{array}$} & $\begin{array}{l}\text { South Branch } \\
\text { Potomac }\end{array}$ & $\begin{array}{l}\text { The Trough } \\
\text { North Fork } \\
\text { South Fork }\end{array}$ \\
\hline & Greenbrier & $\begin{array}{l}\text { Upper Greenbrier } \\
\text { Lower Greenbrier } \\
\text { Muddy Creek }\end{array}$ & & Cacapon & $\begin{array}{l}\text { Trout Run } \\
\text { Cacapon } \\
\text { North River }\end{array}$ \\
\hline & Gauley & $\begin{array}{l}\text { Meadow } \\
\text { Gauley } \\
\text { Cranberry }\end{array}$ & \multirow{8}{*}{$\frac{.}{\frac{0}{1}}$} & Elk & $\begin{array}{l}\text { Birch } \\
\text { Below Lake } \\
\text { Sutton } \\
\text { Above Lake } \\
\text { Sutton }\end{array}$ \\
\hline \multirow{7}{*}{$\begin{array}{l}\frac{\pi}{0} \\
\frac{C}{\pi} \\
00 \\
\frac{C}{0} \\
\frac{1}{0} \\
\sum\end{array}$} & \multirow[t]{2}{*}{ Cheat } & $\begin{array}{l}\text { Upper Cheat } \\
\text { Lower Cheat } \\
\text { Big Sandy } \\
\text { Lower Muddy }\end{array}$ & & Kanawha & $\begin{array}{l}\text { Paint Creek } \\
\text { Pocatalico } \\
\text { Kanawha Falls } \\
\text { Winfield Locks }\end{array}$ \\
\hline & & $\begin{array}{l}\text { Upper Blackwater } \\
\text { Lower NF } \\
\text { Blackwater }\end{array}$ & & \multirow[t]{2}{*}{ Coal } & Little Coal \\
\hline & \multirow{2}{*}{ Monongahela } & $\begin{array}{l}\text { White Day } \\
\text { Dunkard }\end{array}$ & & & $\begin{array}{l}\text { Pond Fork } \\
\text { Lower Spruce Fk }\end{array}$ \\
\hline & & $\begin{array}{l}\text { Deckers } \\
\text { Monongahela }\end{array}$ & & \multirow[t]{2}{*}{ Upper Guy } & $\begin{array}{l}\text { Buffalo Creek } \\
\text { Above R.D. Bailey }\end{array}$ \\
\hline & \multirow[b]{3}{*}{ Tygart } & Three Forks & & & Below R.D. Bailey \\
\hline & & Upper Ty & & \multirow[b]{2}{*}{ Tug } & Tug Fork \\
\hline & & $\begin{array}{l}\text { Tygart } \\
\text { Lower Ty }\end{array}$ & & & $\begin{array}{l}\text { Pigeon Creek } \\
\text { Panther Creek }\end{array}$ \\
\hline
\end{tabular}


Maps and spatial data were developed using ArcMap version 10 software (ESRI, 2011). Stream and watershed shapefiles were downloaded from the West Virginia GIS Technical Center website. All spatial data is projected in a NAD83 UTM Zone 17 projection. A topographic base layer was used to identify municipality locations and road crossings in river segment selection. A point at the center of each river segment was created to represent one geographic location for perceptions of each segment.

\section{Fishery Dataset}

Fishery data for this project were derived from a compiled state dataset with sampling events occurring from 2000-2010. The data were collected by various sources including the WVDEP, USEPA Region 3, West Virginia's Department of Natural Resources, and West Virginia University. Sampling events include electrofishing gear types only. Geographic location was recorded for each sampling event. Wadeable $\left(6-518 \mathrm{~km}^{2}\right)$ and large river $\left(518+\mathrm{km}^{2}\right)$ sampling sites corresponding to the survey were queried creating a baseline dataset of sampling events ( $n=153)$. For each river segment, one sampling event was used to represent the fish assemblage. Some reaches contained multiple sites or multiple sampling events within the ten year period. Expert opinion was used to select sites that best represent the selected river segments (Figure 2). Sites with multiple accurate sampling events were averaged together. Some surveyed river segments did not have adequate fish information and were not used in analysis. 


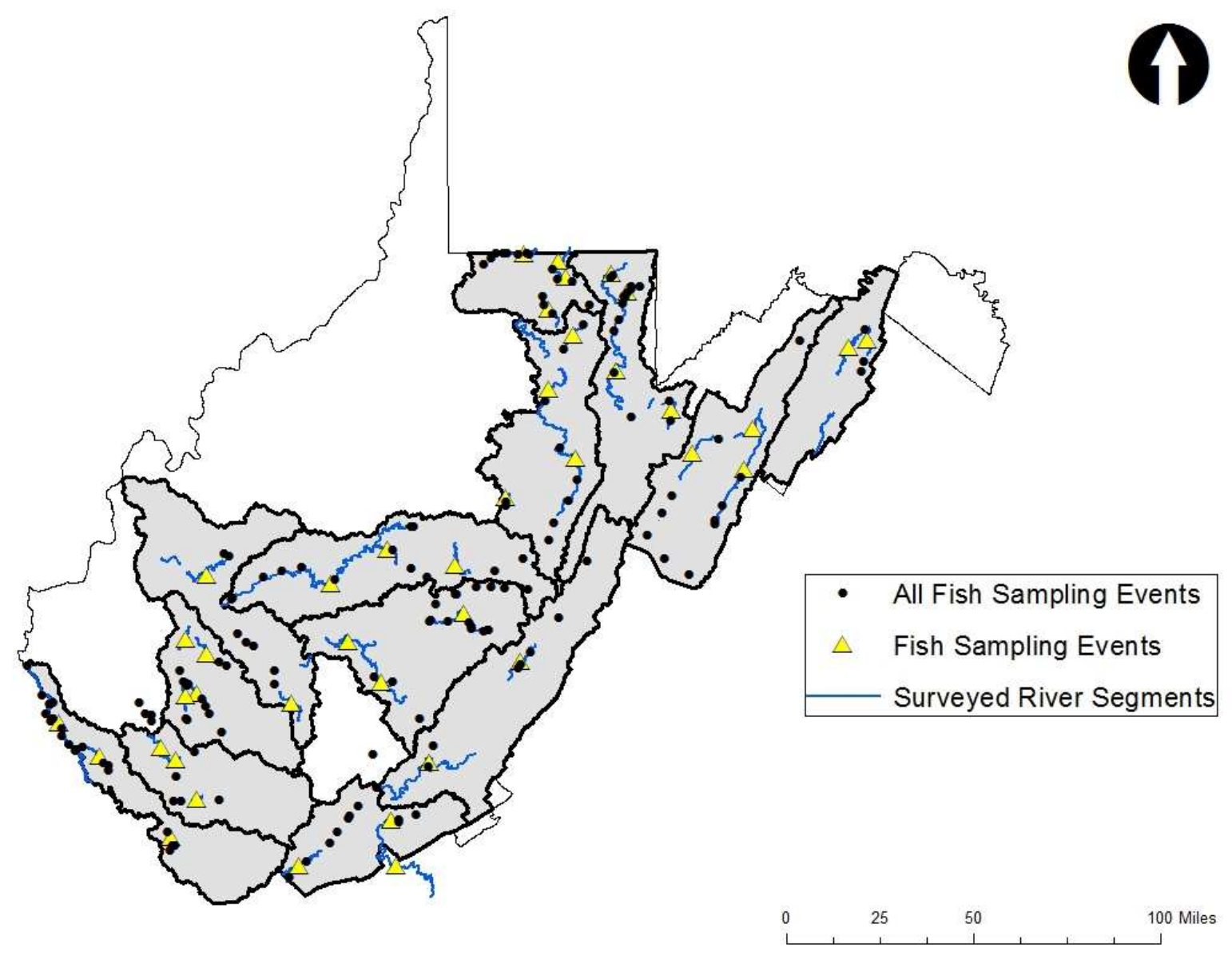

Figure 2. Selected fish sampling events that correspond to the surveyed river segments within each HUC8 watershed $(n=41)$.

Fish community metrics have been calculated for each sampling event (Table 2). Fish community metrics are based upon West Virginia's indices of biotic integrity, previously determined by McCormick et al. (2001); Detenbeck \& Cincotta (2008); Hitt \& Angermeier (2011), and attributes indicative of ecological quality. Intolerant benthic richness, percent intolerant, percent invertivore/piscivore, total species richness, and conservative game 
abundance were the metrics used in analysis for this study. Conservative game abundance consists of a total of 23 species including catfish, trout, and bass species (Appendix A).

Table 2. Fish metrics calculated for each fish sampling event from 2000 to 2010.

\begin{tabular}{l}
\hline Metrics \\
\hline \% Native \\
\% Rock-Gravel Spawner \\
\% Invertivore/piscivore \\
\% Omnivore/herbivore \\
\% Tolerant \\
\% Intolerant \\
Game abundance \\
Game abundance (conservative) \\
Tolerant Benthic Richness \\
Intolerant Benthic Richness \\
Total Species Richness \\
\hline
\end{tabular}

Survey Implementation

A stratified sample based upon watershed organizations and recreational users was used to collect user perception data. This study design is based on the assumption that recreational users of West Virginia watersheds are associated with watershed organizations and have internet access. This assumption has important sampling validity connotations. However, the assumption must be made in order to identify a hidden population of the recreational user. It is not possible to draw a general public sample where every individual of the population has a known chance of being selected by using online surveys. Due to this constraint, a purely random sample of respondents would not have sufficed (Hyman, 1981). Four hundred respondents per surveyed watershed was recommended for this study (Vaske, 2008). Unfortunately, four-hundred respondents per watershed was not possible and the 
reasonable goal for this project was to have a minimum of thirty respondents per watershed survey for statistical analysis. The study was also limited by watershed organization involvement and a lack of time and outreach. In areas where there are no watershed groups or recreational outfitters, sample sizes were expected to be minimal/non-existent. River segments that have sample sizes lower than ten were removed from analysis.

Online surveys were used to gather data from recreational users that corresponded to each HUC8 watershed. Recreational users were defined as in-channel water recreationists (swimming, fishing, or boating). Boating for this study included kayaking, rafting, and canoeing. Swimming included tubing activities due to the direct human contact with the water surface. Use is strictly defined and based upon whole body contact recreation and secondary contact recreation that has been constructed by water quality standards regulations of the Clean Water Act. Detailed definitions are as follows:

10 CSR 20-7.031(1) (C) 8. Whole body contact recreation- Activities in which there is direct human contact with the raw surface water to the point of complete body submergence. The raw water may be ingested accidentally and certain sensitive body organs, such as the eyes, ears and the nose, will be exposed to the water. Although the water may be ingested accidentally, it is not intended to be used as a potable supply unless acceptable treatment is applied. Water so designated is intended to be used for swimming, water skiing or skin diving.

10 CSR 20-7.031(1) (C) 9. Secondary contact recreation- Uses include fishing, wading, commercial and recreational boating, any limited contact incidental to shoreline activities, and activities in which users do not swim or float in the water. These recreational activities may result in contact with the water that is either incidental or accidental and the probability of ingesting appreciable quantities of water is minimal. 
The survey instrument was sent via email as a web-link to watershed organizations and recreational outfitters from May to September of 2012. Methods were modified from Schaefer \& Dillman (1998). Within the five month period, three rounds of sampling occurred. Initially one hundred and fifty-four watershed organizations and recreation outfitters were contacted in May of 2012. Forty-nine of those initial contacts were deliverable via email. When watershed organizations did not exist or were unable to be reached, fishing associations, rafting guides, and watershed experts such as DNR fish biologists and university affiliates were contacted. Approximately a total of eighty primary contacts were successfully emailed. A webpage through the university was created as a user-friendly guide to the surveys (http://grad.davis.wvu.edu/recreational-user-survey). Each watershed had a separate tab showing geographic location and included a brief narrative of each river segment with a link that directed the respondent to each specific watershed survey.

A snowball sampling technique was used to recruit additional respondents within the targeted population (Heckathorn, 2002). Snowball sampling is a non-probability sampling technique that acts like a "growing snowball" by obtaining respondents through a chain-referral sampling event to accumulate enough data to be statistically useful. Individual watershed organizations were asked to administer and distribute the survey among their listservs, websites, and Facebook pages. As the snowball expands, biases are expected to be reduced. The prime method of snowball sampling is interview- based (Atkinson \& Flint, 2001) but with a large online network like Facebook the same outcomes were expected to be effective. Watershed organizations and recreational outfitters as inter-agents in administering the survey were used to: 1- obtain a higher response rate with the assumption that respondents are more 
likely to reply if the survey is being sent by someone of familiarity and trust; 2- maintain privacy to personal information such as email addresses and additional online contact information; and 3- to produce a more accurate representation of user perceptions based on the assumption that persons associated with watershed groups are likely to have the most involvement with the surveyed river segments.

A pilot study was conducted for the Cheat River watershed and Decker's Creek watershed, within the Monongahela watershed. Friends of the Cheat and Friends of Decker's Creek watershed organizations both participated by distributing the survey via Facebook and through their listservs. Both versions of the pilot study were also sent to the Department of Forestry and Natural Resources at West Virginia University via the listserv. Pilot watersheds were selected due to ease and proximity to West Virginia University. A total of 78 recreational users completed the Cheat River pilot survey and 43 completed the Decker's Creek pilot study. The purpose of the pilot was to justify that the snowball sampling technique would be sufficient for collecting perception data from a recreational user population. Based on the pilot study our sample sizes showed responses collected from an online survey would be satisfactory for statistical analysis.

\section{Survey Instrumentation}

The online survey was formatted through the application of SurveyMonkey, an internetbased survey tool. The survey was twenty-three questions in length. The survey instrument collected information on: (1) user demographics; (2) awareness of environmental quality; and (3) the perception of quality (Table 3). In regard to sensitive information demographics such as 
salary, education, and willingness to pay were excluded from the survey as an effort to reduce the nonresponse rate. Nonresponse was defined as those that started the survey but did not finish the survey in its entirety. Respondents were not required to answer each question in order to move forward within the survey. Responses from incomplete surveys were still used to maximize our sample sizes. 
Table 3. Abbreviated survey questions with source, scale, and level of measurement.

\begin{tabular}{|c|c|c|c|c|}
\hline $\begin{array}{l}\text { Question } \\
\text { Number }\end{array}$ & Question & Scale & Citation & $\begin{array}{l}\text { Level of } \\
\text { Measurement }\end{array}$ \\
\hline Q1 & Gender & $\mathrm{M} / \mathrm{F}$ & $\begin{array}{l}\text { Ferriss, 1963; Burger et al., 1998; } \\
\text { Brody et al., 2005; Dogaru et al., } \\
2009\end{array}$ & Nominal \\
\hline Q2 & Age & Open & $\begin{array}{l}\text { Ferriss, 1963; Burger et al., 1998; } \\
\text { Brody et al., 2005; Dogaru et al., } \\
2009\end{array}$ & Ordinal \\
\hline Q3 & Are you a resident of WV? & $\mathrm{Y} / \mathrm{N}$ & $\begin{array}{l}\text { Ferriss, 1963; Burger et al., 1998; } \\
\text { Brody et al., 2005; Dogaru et al., } \\
2009\end{array}$ & Nominal \\
\hline Q4 & If yes, how long? & Whole life, $10+$ years, $5-9$ years, $<5$ years & & Ordinal \\
\hline Q5 & $\begin{array}{l}\text { Have you participated in fishing, } \\
\text { swimming, boating in last } 12 \\
\text { months? }\end{array}$ & $\mathrm{Y} / \mathrm{N}$ & & Nominal \\
\hline Q6 & $\begin{array}{l}\text { If you participated in any of these } \\
\text { activities, how far did you travel to } \\
\text { these locations? }\end{array}$ & Open & $\begin{array}{l}\text { Marisa Mazzotta, Enviornmental } \\
\text { \& Resource Economist, EPA } \\
\text { Region } 3\end{array}$ & Interval \\
\hline Q7 & $\begin{array}{l}\text { If you fish, swim, or boat at other } \\
\text { sites besides these, how far (IN } \\
\text { MILES) do you typically travel to } \\
\text { participate in each activity? }\end{array}$ & Open & $\begin{array}{l}\text { Marisa Mazzotta, Enviornmental } \\
\text { \& Resource Economist, EPA } \\
\text { Region } 3\end{array}$ & ordinal \\
\hline Q8 & Rank activity importance & Most important, moderately important, & Butler \& Redfield, 1991 & Ordinal \\
\hline
\end{tabular}


least important, not important

\begin{tabular}{|c|c|c|c|c|}
\hline Q9 & $\begin{array}{l}\text { On average, how many days to you } \\
\text { spend per year fishing, swimming, } \\
\text { boating? }\end{array}$ & $0,1,2-4,5-10,11-20,20+$ & Burger et al., 1998 & Ratio \\
\hline \multirow[t]{2}{*}{ Q10 } & Are there any activities unsuitable? & Suitable, unsuitable & Mullens \& Bristow, 2003 & Ordinal \\
\hline & $\begin{array}{l}\text { If other, please state why it is } \\
\text { unsuitable? }\end{array}$ & Open & & \\
\hline Q11 & $\begin{array}{l}\text { Indicate the best choice that } \\
\text { describes your opinion on how } \\
\text { suitable the water is }\end{array}$ & $\begin{array}{l}\text { Beautiful, excellent, slightly impaired, } \\
\text { desire is reduced, nearly impossible }\end{array}$ & Smeltzer \& Heiskary, 1990 & Ordinal \\
\hline Q12 & $\begin{array}{l}\text { Indicate environmental problems } \\
\text { that affect the river }\end{array}$ & $\begin{array}{l}\text { Most important, moderately important, } \\
\text { least important, not important }\end{array}$ & Butler \& Redfield, 1991 & Ordinal \\
\hline Q13 & $\begin{array}{l}\text { Rate the overall water quality of each } \\
\text { location }\end{array}$ & Poor, fair, good, very good, excellent & Burns (in-person communication) & Ordinal \\
\hline Q14 & $\begin{array}{l}\text { If water quality to be improved would } \\
\text { you consider swimming, fishing, or } \\
\text { boating? }\end{array}$ & $\begin{array}{l}\text { More often, less often, same amount, } \\
\text { currently at best level }\end{array}$ & Petty (in-person communication) & Ordinal \\
\hline Q15 & $\begin{array}{l}\text { Have you fished any of the listed river } \\
\text { sections in the last two years? }\end{array}$ & $\mathrm{Y} / \mathrm{N}$ & & Ordinal \\
\hline Q16 & Which sections? & & & Nominal \\
\hline Q17 & $\begin{array}{l}\text { What species do you catch when } \\
\text { fishing these river sections? }\end{array}$ & Open & $\begin{array}{l}\text { Marisa Mazzotta, Enviornmental } \\
\text { \& Resource Economist, EPA }\end{array}$ & Nominal \\
\hline
\end{tabular}


Region 3

\begin{tabular}{|c|c|c|c|c|}
\hline Q18 & $\begin{array}{l}\text { How many fish do you catch on a } \\
\text { typical fishing day? }\end{array}$ & Open & & Ratio \\
\hline Q19 & Do you practice catch and release? & $\begin{array}{l}\text { Always, sometimes, never, have not fished } \\
\text { this section }\end{array}$ & & Ordinal \\
\hline Q20 & $\begin{array}{l}\text { Do you consume recreationally } \\
\text { caught fish? }\end{array}$ & $\mathrm{Y} / \mathrm{N}$ & $\begin{array}{l}\text { USEPA (2012) OMB Control No. } \\
2040-0283\end{array}$ & Ordinal \\
\hline Q21 & $\begin{array}{l}\text { Do you consider the fish to be } \\
\text { healthy to eat? }\end{array}$ & $\begin{array}{l}\text { Strongly disagree, disagree, neutral, agree, } \\
\text { strongly agree }\end{array}$ & Verbeke et al., 2004 & Ordinal \\
\hline \multirow[t]{2}{*}{ Q22 } & $\begin{array}{l}\text { Do you belong to a watershed } \\
\text { organization or a water-based } \\
\text { environmental group? }\end{array}$ & $\mathrm{Y} / \mathrm{N}$ & & Ordinal \\
\hline & If yes, what group? & Open & & \\
\hline Q23 & Additional comments & Open & & \\
\hline
\end{tabular}


Respondents were asked questions specific to particular river segments for each watershed. The Monongahela watershed was used as a template in setting up the survey design. The template design consisted of each watershed having four representative river segments where the respondents were asked to rate or rank the conditions of each segment. River segments were intended to include two large rivers and two tributaries that depict "poor" and "good" water quality condition. However, the corresponding river segments were dependent upon each specific HUC8 and did not always follow the ideal template design of two tributaries and two large rivers. All survey questions were modified from sourced literature and the majority of questions were scaled. A mail format of the survey is provided within the appendix as a substitute of the online survey due to formatting issues.

A pre-notice regarding the survey was sent to the first one hundred watershed groups that were contacted. It's been shown in past literature that respondents are less likely to respond when email questionnaires are sent without prior notification (Mehta \& Sivadas, 1995; Schaefer \& Dillman, 1998). Prior notification has also been shown to increase credibility and enhance the survey's snowball effect. Unfortunately, time became a constraint and we were unable to pre-notify every single contact. With such quick responses through the web, most respondents replied to the survey within the first two weeks of receiving the weblink. In a study done comparing email and mail, mail surveys took 11.8 days to return and email surveys were returned in 7.6 days (Sheehan \& McMillan, 1999; Sheehan, 2001;). Email provided an easier and more immediate means of response from the targeted population. Reminder emails were 
sent to those groups who expressed positive feedback and interest in the study. A reminder notification for an email survey has found responses to increase by $25 \%$ (Sheehan \& Hoy, 1997; Sheehan, 2001).

\section{Limitations and Delimitations}

Study Design- This study included water recreators and individuals that participate in boating, swimming, and fishing activities only. It did not take into account those that enjoy water resources aesthetically or enjoy wildlife viewing surrounding natural areas. This limitation allows for sampling bias by excluding those that do not fish, swim, or boat.

With the use of an internet-based survey method, we were able to save time, limit costs, receive an immediate response, and collect responses remotely. Unfortunately, we were limited by the number of responses based on this method and created unwanted biased results. Duda (2011) identified four main disadvantages when using an online survey method: sample validity, non-response bias, stakeholder bias, and unverified respondents.

Every member of the population should have an equal chance of being selected for the study. For our recreational user population, a user needed to have internet access and belong to a watershed organization or recreational outfitter in order to respond to the survey. Sampling validity was reduced by initially sampling a closed population in which every member with a verified email address and internet access subscribed to a watershed organization had an opportunity in responding (Duda, 2011). This is based on the assumption that watershed organizations promoted the survey and sent the survey via listserv. To increase our response, a website was built to promote the survey thus no longer sustaining a closed sample population. 
This sampling limitation resulted in small and unequal sample sizes among watersheds. Our results cannot represent the entire population of water recreationists in West Virginia but it allowed patterns and trends to exist from an exploratory approach.

Nonresponse bias occurs when respondents are different from those who did not respond in reference to their demographic or attitudinal background (Sax et al., 2003). People who respond to an online survey are likely interested in the topic and more willing to participate (Duda \& Nobile, 2011). A snowball sampling technique was used as an attempt to reduce non-response bias. Out of those who responded to the survey forty-three percent said they were not members of a watershed organization or environmental group $(n=232)$. Unfortunately, only 232 out of 421 total respondents chose to answer and we cannot conclude if nonresponse bias was successfully reduced.

Each response was recorded and identified by IP address through SurveyMonkey as a way to limit stakeholder bias. If the same survey was completed multiple times with the same IP address, hypothetically we would be able to recognize and remove stakeholder bias.

Realistically, surveys could have been completed from public locations or shared computers. In the Monongahela survey, eleven responses are derived from only five different IP addresses. Survey results were analyzed by each response and we did not remove duplicate IP address responses therefore this study likely has stakeholder bias. Even with IP address identification and using watershed groups as a way to target the hidden water recreationist population, the inability to verify who responds remains as another limitation. 
Other limitations due to sampling design include scale and stream comparisons. Survey questions were asked on two scales, watershed and river segment levels. Multiple scales of measurement caused the survey to be overly complex and made it difficult in comparing information (i.e. participation and perception ratings). Surveying watersheds across a large geographic area was a huge undertaking from a remote location within a short time frame. Also due to our small sample sizes, results were statistically weak and considered more qualitative and exploratory than quantitative.

Fishery Dataset- Fish metrics for this study were calculated and are intended to be used for the development of a West Virginia IBI (A. Anderson, unpublished data). It is assumed that fish samples are a balanced representation of the community, represent a larger geographic area, and the collector is trained in local fish fauna (Karr, 1981). All fish data was compiled from multiple collectors within varying time frames (season \& year) likely incorporating sampling bias. Multiple collectors, when collecting the same data, tend to sample slightly different and can file data in different formats making it difficult for any one state to keep a consistent record when compiling a large dataset (Doremus, 2006). Limitations in the dataset include missing values and inaccurate representations of surveyed river segments. Best professional judgment was used in removing sampling events with high sampling error.

Although fish metrics can be used as bioindicators, fishery data cannot be completely conclusive regarding stream health. Using fish as indicators of steam health rather than using multi-bioassessments and chemical monitoring may underestimate local degradation (Type II error) and has the potential of being a limitation for this study (Hitt \& Angermeier,2011). If 
West Virginia's stream condition index (WVSCI), a benthic macroinvertebrate based index, was used in addition to fish metrics, results may have differed when compared to user perceptions.

\section{Statistical Analysis}

Recreational User Perceptions of West Virginia- Once collected, data was downloaded from the SurveyMonkey webpage into Excel and analyzed within the R Statistical Package. Demographic information was organized by respondent ID and grouped by HUC8 watershed. Yes/No responses were coded as binary. Age, mileage, and number of fish caught were kept in their default units. Likert scales were inverted during analysis to allow ratings to increase from poor to excellent. Non-numeric errors were removed from the dataset. Mileage outliers greater than $483 \mathrm{~km}$ were also removed. Demographics were compared using Kruskal-Wallis and Pearson's chi-square tests respectively. Summary statistics were calculated for each HUC8 watershed and across the entire study area.

With the exception of the demographic data, all responses were grouped by corresponding river segment within each HUC8 watershed. Responses were separated by each individual rating per question. The number of respondents was recorded by each individual rating per question. (e.g., twelve respondents rated the South Branch Potomac river segment to be most important for boating activities). Mean values were calculated for each question by river segment and by activity type. Activity participation was calculated based on the percentage of responses by HUC8 watershed and was compared among activity types, watersheds, and the entire study area. Due to the survey design, comparisons made between river segments were unequal and samples were assumed independent across watersheds. The Tug and Upper Guyandotte watersheds and their associated river segments were removed 
from further analysis due to a small sample $(n=3)$; resulting in a total of 41 river segments used in analyzing water recreational user perceptions.

Activity participation and mean perceptions of overall water quality and overall suitability were compared on a watershed scale to determine if participation was correlated with perception. A spearman rank correlation test was used to test if participation and mean perceptions of water quality and suitability were related. Mean perceptions of overall water quality, overall suitability, and activity participation were ranked and plotted. Mean perception of overall water quality and overall suitability for each activity type were compared on a river segment level to determine if the perception of water quality and suitability changed based on activity. A two-way ANOVA without replication was used to determine if mean perception of overall water quality and overall suitability differed depending on activity type (swimming, fishing, and boating). The ANOVA test was followed by the Tukey-Kramer posthoc test for all pairwise comparisons. All significance testing used an alpha value of 0.05 .

Relationships between perceptions and biological condition- Perception scores were combined to create an overall user perception for each river segment. Perception of overall water quality and suitability for each activity type were used for the composites. The perception of importance was not used because the question was phrased very similarly to the suitability question within the survey. Also, importance was used on a 4-point scale whereas suitability and overall water quality relied on a 5-point scale. Water quality and suitability perceptions represent the mean ratings of all three activity types (swimming, fishing, and boating). Mean ratings for each activity type were averaged together to determine an overall 
mean water quality and overall mean suitability rating for each river segment. Swimmable, fishable, and boatable perception scores are summations of mean overall water quality and suitability ratings (Figure 3). Perceived water quality and perceived suitability were double weighted to establish swimming, fishing, and boating composite ratings. A total of thirty-four river segments were used in comparisons between perceptions and fishery assemblage data. Fish metrics that have been used in comparisons include: percent invertivore/piscivore, percent intolerant species, conservative game abundance, intolerant benthic species richness, and total species richness. Fish metrics were compared to composite perception scores. All river segments were ranked using equal ties and plotted from worst to best. Ranked values were plotted separately based on river segment size (wadeable vs. large river) due to different electrofishing sampling efforts. A spearman rank correlation test was used to determine if

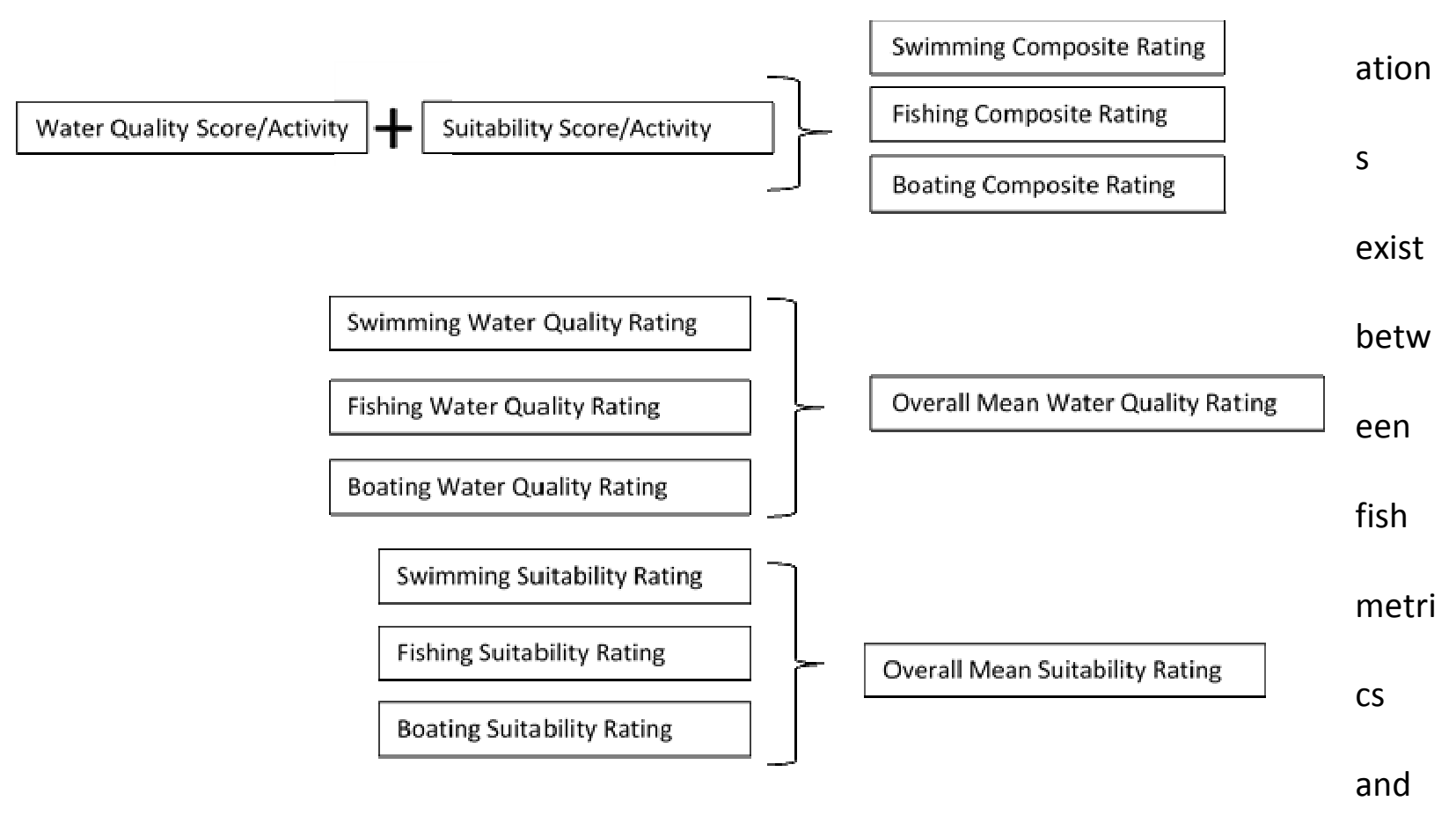

perception data. 
Figure 3. Conceptual diagram of composited perception ratings

303(d) listed river segments and their sources of impairment were identified to determine if impairment had an association with the perception of water quality and suitability. Impairment data was taken from the 2010 \& 2012 WVDEP Integrated Water Quality Monitoring and Assessment Reports (WVDEP 2010, 2012). Impairments listed for a river but not within the surveyed river segment area were not used. The source of impairment was compared to the mean suitability and water quality score for each source to determine how sources are perceived. Impaired and not impaired river segments were plotted by the perception of overall water quality and suitability by activity respectively. A two sample t-test assuming unequal variance was used to determine if mean water quality scores were rated as the same between fishing and boating activities.

Spatial patterns of user perceptions- ArcMap version 10 software was used to identify spatial clusters of perception across watersheds and across regions. Spatial clustering are 
identified through spatial autocorrelation, a phenomenon that occurs when the spatial distribution of a variable of interest (perceptions) display a nonrandom pattern in geographic space (Brody et al., 2005). Cluster and hot spot analysis methods followed techniques outlined by Brody et al. (2005). Global Moran's / test for significance was used to determine which river segments were significantly clustered. Calculations were based on a euclidean distance suggesting that each feature (mean perception rating per river segment) has at least one neighboring feature. Perceptions of environmental stressors, fishing suitability and composite scores of suitability and perception of water quality in relation to swimming, fishing, and boating were used in the cluster analysis. Perceptions on a HUC8 scaled were not used due to sample size of less than thirty $(n=11)$.

\section{CHAPTER FOUR \\ RESULTS}

\section{Recreational User Perceptions of West Virginia}

Survey Responses-A total of 421 water recreationists responded to the study from May to September of 2012 (Table 4.) The Monongahela and Cheat watershed surveys had the highest number of started and completed surveys but had a low overall completed response rate. Response numbers within the Monongahela and Cheat surveys may have declined due to the pilot survey that was conducted in March of 2012. The Kanawha, Upper Guyandotte, and Tug surveys had the lowest number of respondents due to the difficulty in contacting watershed organizations or environmental groups within those areas.

Table 4. Total Survey Responses by watershed. "Started" refers to all respondents who opened the survey link. "Completed" refers to all respondents who answered every question. 


\begin{tabular}{lrrr}
\hline Watershed: & Started & Completed & \% Complete \\
\hline Monongahela & 115 & 56 & 48.7 \\
Cheat & 70 & 31 & 44.3 \\
Greenbrier & 44 & 30 & 68.2 \\
Coal & 37 & 21 & 56.8 \\
Elk & 31 & 19 & 61.3 \\
South Branch Potomac & 29 & 21 & 72.4 \\
Gauley & 25 & 19 & 76 \\
Tygart & 21 & 14 & 66.7 \\
Middle New & 18 & 12 & 66.7 \\
Cacapon & 14 & 12 & 85.7 \\
Kanawha & 11 & 6 & 54.5 \\
Upper Guyandotte & 3 & 1 & 33.3 \\
Tug & 3 & 1 & 33.3 \\
\hline Total Responses & 421 & 243 & 57.7 \\
Pilot:Cheat & 81 & 43 & 53.1 \\
Pilot:Monongahela & 141 & 78 & 55.3 \\
Pilot: Total Responses & 222 & 121 & 54.5 \\
\hline
\end{tabular}

Demographics-I observed significant differences in demographics among HUC8 watersheds

(Table 5.). Age, gender, boating participation and respondents who have fished in the last two years all differed significantly among watersheds. The mean number of fish caught in a given trip, distance traveled to reach a particular watershed for recreation, fishing and swimming participation also were highly significantly different among watersheds. Residency and watershed organization involvement, however, were not significantly different across the study area.

Table 5. Demographic variables compared among watersheds. ${ }^{*} p=0.05, * * p=0.01, * * * p=0.001$ level.

\begin{tabular}{lccl}
\hline Demographic Variables & Statistical Test & Significance & P-Value \\
\hline Mean Age & & $*$ & 0.03 \\
Mean Traveled Mileage & Kruskal-Wallis & $* * *$ & $1.17 \mathrm{e}-11$ \\
Mean Number of Caught Fish & & $* * *$ & $<2.2 \mathrm{e}-16$ \\
\hline
\end{tabular}




\begin{tabular}{lccl}
\hline Percent Male & $*$ & 0.05 \\
Percent Resident & - & 0.12 \\
Percent Fishing Participation & $* * *$ & $1.61 \mathrm{e}-10$ \\
Percent Boating Participation & Pearson's Chi-Square & $*$ & 0.02 \\
Percent Swimming Participation & $* * *$ & 0.001 \\
Percent Fished in the last two years & $*$ & 0.05 \\
Percent Belong to a Watershed Org & - & 0.21 \\
\hline
\end{tabular}

Respondents, on average, were willing to travel furthest to recreate within the Elk

watershed (Table 6.). All medians were below $161 \mathrm{~km}$ with the Middle New, South Branch

Potomac, and Gauley watersheds showing the highest variability. The majority of respondents

would not travel more than $322 \mathrm{~km}$ to reach a particular watershed. The mean number of fish

caught on a typical fishing day ranges from one to approximately twenty (Figure 4.). With the

exception of the Cheat, Tug, and Upper Guyandotte watersheds, the number of fish caught was

highly variable. Cheat responses were very consistent on catching only one to two fish on a typical day $(n=31)$.

Table 6. Distance $(\mathrm{km})$ traveled for water-based recreation. Table is ordered by mean $\mathrm{km}$ traveled.

\begin{tabular}{lccccccccc}
\hline \multicolumn{1}{c}{ Watershed } & $\begin{array}{c}\text { Number of } \\
\text { Respondents }\end{array}$ & $\begin{array}{c}\text { Total } \\
\text { Response }\end{array}$ & $\begin{array}{c}\text { (\%) } \\
\text { Response }\end{array}$ & Median & Mean & SE & Min & Max & Range \\
\hline Middle New & 16 & 18 & 89 & 127.2 & 194.6 & 72.5 & 64.4 & 209.3 & 144.9 \\
Elk & 28 & 31 & 90 & 161.0 & 154.9 & 12.4 & 1.6 & 120.8 & 119.1 \\
SB Potomac & 23 & 29 & 79 & 112.7 & 143.6 & 34.1 & 1.6 & 281.8 & 280.1 \\
Greenbrier & 41 & 44 & 93 & 112.7 & 138.0 & 45.6 & 16.1 & 515.2 & 499.1 \\
Gauley & 24 & 25 & 96 & 88.6 & 123.8 & 21.6 & 12.9 & 402.5 & 389.6 \\
Cacapon & 8 & 14 & 57 & 44.3 & 85.0 & 26.2 & 0.0 & 402.5 & 402.5 \\
Cheat & 48 & 70 & 69 & 48.3 & 79.1 & 16.9 & 0.0 & 322.0 & 322.0 \\
Tygart & 18 & 21 & 86 & 28.2 & 67.9 & 17.5 & 0.0 & 402.5 & 402.5 \\
Coal & 28 & 37 & 76 & 28.2 & 61.8 & 18.5 & 1.6 & 322.0 & 320.4 \\
Kanawha & 9 & 11 & 82 & 16.1 & 32.4 & 12.2 & 0.0 & 362.3 & 362.3
\end{tabular}




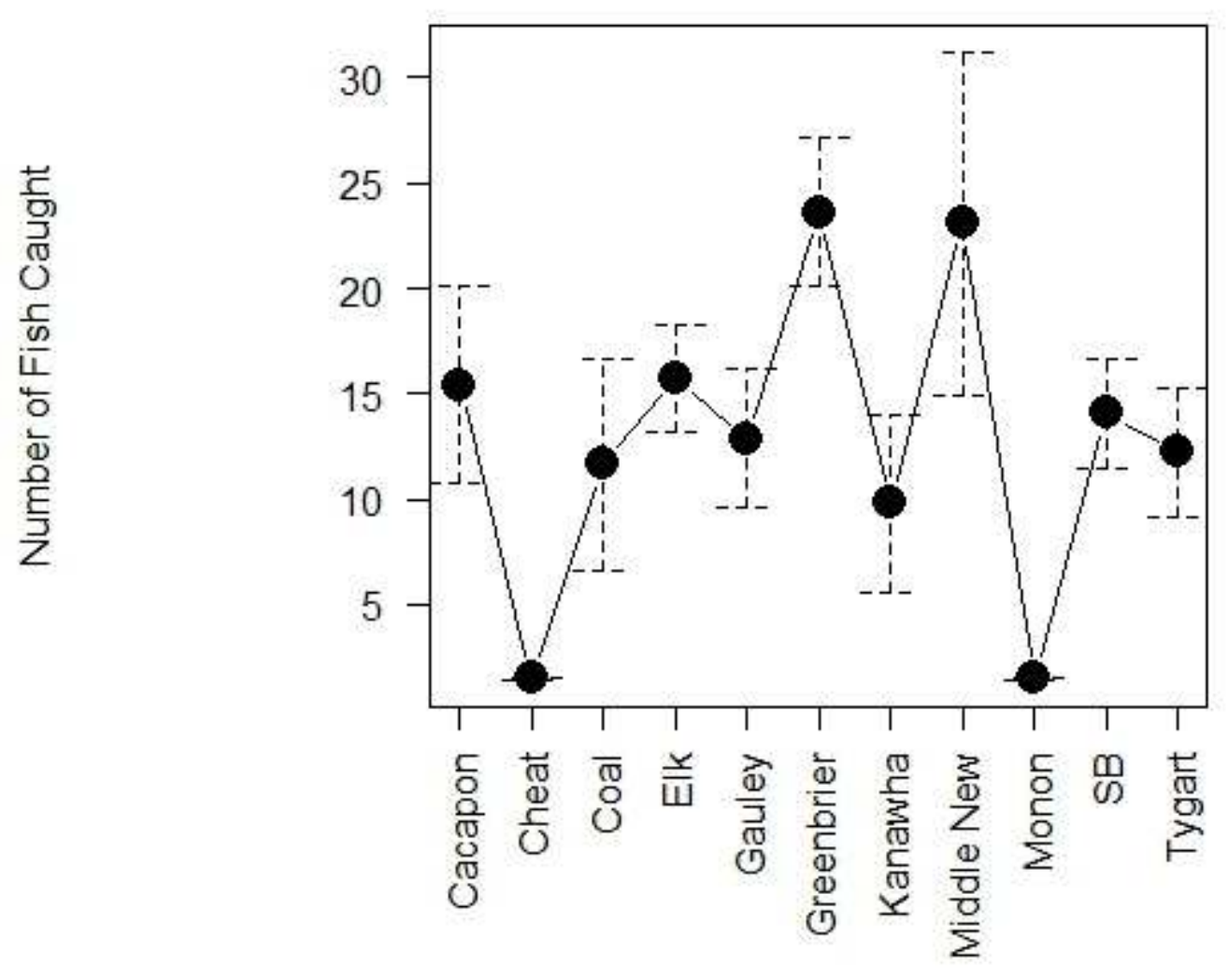

\section{Watersheds}

Figure 4. The mean and standard deviation of fish caught within a typical fishing day by watershed. 
Recreationists that had fished within the last two years were asked to list targeted species and location. Ninety percent of anglers listed their targeted species. Few respondents mentioned location with targeted species responses. Targeted species were categorized and grouped together by watershed rather than by river segment for a lack of data. Species were grouped into the following categories: trout, bass, hybrid bass, sunfish \& panfish, catfish, cyprinids, pike \& walleye, bait fishes, drums, and miscellaneous (Table 7). It was not feasible to look at each species separately due to the wide variation in responses. The number of respondents that fished for a species within each fish category was recorded. (Table8). Results were then descriptively compared to "favorite waters" determined by West Virginia's 2013 Fishing Regulations Summary Report (WV Department of Natural Resources 2013). Favorite waters are grouped by popular targeted species and listed by rivers. Direct comparisons could not be made due to unspecified locations from the survey regarding popular species and generalization of species (i.e. catfish rather than channel catfish). Comparisons were only made using mainstem favorite waters from the WVDNR Fishing Regulations Summary; no tributary data was used. 
Table 7. Targeted fish species within the last two years.

\begin{tabular}{|c|c|}
\hline Fish Categories & Fish Species \\
\hline \multirow{5}{*}{ Trout } & Brook Trout (Salvelinus fontinalis) \\
\hline & Brown Trout (Salmo trutta) \\
\hline & Golden Rainbow Trout (Oncorhynchus mykiss) \\
\hline & Rainbow Trout (Oncorhynchus mykiss) \\
\hline & Tiger Trout(Salmo trutta $\times$ Salvelinus fontinalis) \\
\hline \multirow{3}{*}{ Bass } & Largemouth Bass (Micropterus salmoides) \\
\hline & Smallmouth Bass (Micropterus dolomieu) \\
\hline & Spotted Bass (Micropterus punctulatus) \\
\hline \multirow{3}{*}{ Hybrid Bass } & Hybrid Stiped Bass (Morone saxatilis x Morone chrysops) \\
\hline & Striped Bass (Morone saxatilis) \\
\hline & White Bass (Morone chrysops) \\
\hline \multirow{6}{*}{ Sunfish \& Panfish } & Bluegill (Lepomis macrochirus) \\
\hline & Crappie (Pomoxis spp.) \\
\hline & Sunfish (Centrarchidae) \\
\hline & Perch (Perca spp.) \\
\hline & Redeye Bass (Micropterus coosae) \\
\hline & Rockbass (Ambloplites rupestris) \\
\hline \multirow{3}{*}{ Catfish } & Blue Catfish (Ictalurus furcatus) \\
\hline & Channel Catfish (Ictalurus punctatus) \\
\hline & Flathead Catfish (Pylodictis olivaris) \\
\hline \multirow{5}{*}{ Cyprinids } & Carp (Cyprinidae) \\
\hline & Chubs (Cyprinidae) \\
\hline & Fallfish (Semotilus corporalis) \\
\hline & River Redhorse (Moxostoma carinatum) \\
\hline & White Sucker (Catostomus commersonii) \\
\hline \multirow{2}{*}{ Dike \& Walleye Family } & Pickerel (Esox spp.) \\
\hline & Muskellunge (Esox masquinongy) \\
\hline
\end{tabular}




\begin{tabular}{cl} 
& $\begin{array}{l}\text { Sauger (Sander canadensis) } \\
\text { Walleye (Sander vitreus) }\end{array}$ \\
\hline \multirow{3}{*}{ Bait Fishes } & Darters (Percidae) \\
& Shiners \\
& Minnows \\
\hline Drums & Freshwater Drum (Aplodinotus grunniens) \\
\hline Misc & Gar (Lepisosteidae) \\
& Mooneye (Hiodontidae) \\
& Paddlefish (Polyodontidae) \\
\hline
\end{tabular}

Table 8. The number of anglers that have fished in the last two years and their targeted fish category by watershed. Bold count data refers to watersheds with the highest number of anglers fishing within a given fish category.

\begin{tabular}{lccccccccccc}
\hline Watershed & $\begin{array}{c}\text { \# of } \\
\text { Resp. }\end{array}$ & Trout & Bass & $\begin{array}{c}\text { Hybrid } \\
\text { Bass }\end{array}$ & $\begin{array}{c}\text { Sunfish } \\
\text { \& } \\
\text { Panfish }\end{array}$ & Catfish & Cyprinids & $\begin{array}{c}\text { Pike \& } \\
\text { Walleye } \\
\text { Family }\end{array}$ & $\begin{array}{c}\text { Bait } \\
\text { Fishes }\end{array}$ & Drums & Misc \\
\hline Kanawha & 5 & 3 & 4 & 2 & 4 & 3 & 1 & 4 & 0 & $\mathbf{4}$ & 1 \\
Cacapon & 7 & 2 & 6 & 0 & 4 & 0 & 1 & 0 & 0 & 0 & 0 \\
Gauley & 8 & 7 & 6 & 0 & 0 & 1 & 0 & 0 & 0 & 0 & 0 \\
Tygart & 8 & 6 & 5 & 1 & 5 & 2 & 1 & 3 & 1 & 1 & 0 \\
M. New & 9 & 3 & 9 & 0 & 5 & 2 & 1 & 3 & 1 & 0 & 0 \\
SB Potomac & 13 & 7 & 12 & 0 & 6 & 3 & $\mathbf{4}$ & 0 & 0 & 0 & 0 \\
Coal & 14 & 3 & 11 & $\mathbf{3}$ & 5 & $\mathbf{7}$ & $\mathbf{5}$ & 3 & 0 & 1 & 0 \\
Cheat & 16 & $\mathbf{1 2}$ & 13 & 0 & 5 & 1 & 3 & 0 & 0 & 0 & 0 \\
Elk & 17 & $\mathbf{1 3}$ & 13 & 1 & 7 & 2 & 1 & $\mathbf{6}$ & 0 & 1 & 0 \\
Monongahela & 24 & 4 & $\mathbf{1 8}$ & $\mathbf{5}$ & $\mathbf{1 3}$ & $\mathbf{6}$ & 2 & $\mathbf{7}$ & 1 & 0 & 1 \\
Greenbrier & 25 & $\mathbf{1 2}$ & $\mathbf{2 5}$ & 0 & $\mathbf{1 7}$ & 2 & 3 & 0 & 0 & 0 & 0 \\
\hline Study Area & 146 & $\mathbf{7 2}$ & 122 & 12 & 71 & 29 & 22 & 26 & 3 & 7 & 2 \\
\hline
\end{tabular}

Study Area Demographics- Within the entire study area, the majority of respondents were male residents with a mean age of 45 years old \pm 15 years (Table 9.). Out of those residents, $66 \%$ have lived in West Virginia their entire life. The most popular water recreational activities were boating activities (68\% of respondents) followed by fishing (64\%), and swimming (54\%) activities. Fifty seven percent of those who responded belong to a watershed or environmental organization. The average distance traveled within each watershed was $93 \mathrm{~km} \pm 6.4 \mathrm{~km}$. 
Respondents will travel further to fish outside of each watershed at an average of $100 \mathrm{~km} \pm$ $6.4 \mathrm{~km}$.

Table 9. Summary statistics of demographic variables for all responses across all thirteen watersheds.

Demographic Summary of Study Area

\begin{tabular}{|c|c|c|c|c|c|}
\hline Variable & $\begin{array}{c}\text { Number of } \\
\text { Respondents }\end{array}$ & $\begin{array}{c}\text { Total } \\
\text { Responses }\end{array}$ & Percent (\%) & Mean & SE \\
\hline Male & 320 & 414 & 77 & - & - \\
\hline Female & 94 & 414 & 23 & - & - \\
\hline Age & 412 & 421 & - & 45 & 15 \\
\hline WV Residents & 355 & 413 & 86 & - & - \\
\hline Lifetime Residents & 205 & 312 & 66 & - & - \\
\hline Participate in Swimming & 179 & 330 & 54 & - & - \\
\hline Participate in Fishing & 222 & 345 & 64 & - & - \\
\hline Participate in Boating & 238 & 348 & 68 & - & - \\
\hline Fished in the last 2 years & 163 & 251 & 65 & - & - \\
\hline $\begin{array}{l}\text { Belong to a Watershed/Environment } \\
\text { Organization }\end{array}$ & 131 & 232 & 57 & - & - \\
\hline Kilometers traveled within watersheds & 330 & 421 & - & 93 & 6 \\
\hline $\begin{array}{l}\text { Kilometers traveled outside of } \\
\text { watershed to swim }\end{array}$ & 202 & 421 & - & 60 & 6 \\
\hline $\begin{array}{l}\text { Kilometers traveled outside of } \\
\text { watershed to fish }\end{array}$ & 242 & 421 & - & 100 & 6 \\
\hline $\begin{array}{l}\text { Kilometers traveled outside of } \\
\text { watershed to boat }\end{array}$ & 252 & 421 & - & 87 & 6 \\
\hline
\end{tabular}

Activity Participation- The Middle New River watershed had the highest amount of participation overall (Table 10.). The majority of respondents prefer fishing and boating activities over swimming activities. The Middle New, Greenbrier, Gauley, and Coal watersheds had a higher percentage of respondents who boat compared to the statewide average. The Elk, Middle New, and Kanawha watersheds had the highest fishing participation. Fishing 
participation was very low for the Monongahela and Cheat watersheds. Swimming participation was the most variable out of the three activities across watersheds. Within the Cacapon watershed swimming was the most popular activity and was the second most popular swimming location behind the Tygart Valley watershed. Only three watersheds, the South Branch Potomac, Kanawha, and Monongahela, were below the statewide average for swimming activities. 
Table 10. Activity Participation by watershed. Percent response refers to the percent of respondents who stated they participated within a given activity. Each respondent was able to select multiple activities. Watersheds are ordered by highest overall response percent expressed in bold.

Activity Participation

\begin{tabular}{|c|c|c|c|c|c|c|c|c|c|}
\hline \multirow[b]{2}{*}{ Watershed } & \multicolumn{3}{|c|}{ Swimming } & \multicolumn{3}{|c|}{ Fishing } & \multicolumn{3}{|c|}{ Boating } \\
\hline & $\begin{array}{c}\text { Number of } \\
\text { Respondents }\end{array}$ & $\begin{array}{c}\text { Total } \\
\text { Response }\end{array}$ & $\begin{array}{c}(\%) \\
\text { Response }\end{array}$ & $\begin{array}{c}\text { Number of } \\
\text { Respondents }\end{array}$ & $\begin{array}{c}\text { Total } \\
\text { Response }\end{array}$ & $\begin{array}{c}(\%) \\
\text { Response } \\
\end{array}$ & $\begin{array}{c}\text { Number of } \\
\text { Respondents }\end{array}$ & $\begin{array}{c}\text { Total } \\
\text { Response }\end{array}$ & $\begin{array}{c}(\%) \\
\text { Response }\end{array}$ \\
\hline Middle New & 10 & 12 & 83 & 12 & 13 & 92 & 13 & 14 & 93 \\
\hline Greenbrier & 24 & 36 & 67 & 33 & 38 & 87 & 31 & 36 & 86 \\
\hline Elk & 13 & 20 & 65 & 26 & 26 & 100 & 14 & 24 & 58 \\
\hline Tygart & 14 & 18 & 78 & 14 & 17 & 82 & 11 & 18 & 61 \\
\hline SB Potomac & 10 & 12 & 83 & 20 & 24 & 83 & 13 & 24 & 54 \\
\hline Coal & 20 & 31 & 65 & 24 & 33 & 73 & 26 & 33 & 79 \\
\hline Gauley & 13 & 19 & 68 & 13 & 22 & 59 & 17 & 21 & 81 \\
\hline Cacapon & 7 & 10 & 70 & 5 & 9 & 56 & 6 & 10 & 60 \\
\hline Tug Fork & 1 & 2 & 50 & 2 & 3 & 67 & 1 & 2 & 50 \\
\hline Cheat & 30 & 55 & 55 & 24 & 55 & 44 & 35 & 57 & 61 \\
\hline Kanawha & 2 & 10 & 20 & 9 & 10 & 90 & 5 & 10 & 50 \\
\hline Monongahela & 35 & 94 & 37 & 38 & 93 & 41 & 66 & 100 & 66 \\
\hline U Guyandotte & 0 & 1 & 0 & 2 & 2 & 100 & 0 & 1 & 0 \\
\hline Study Area & 179 & 330 & 54 & 222 & 345 & 64 & 238 & 348 & 68 \\
\hline
\end{tabular}


Participation Compared to Perceptions of Water Quality and Suitability- Comparisons were determined based upon the HUC 8 watershed level (Figure 5.). Mean perception ratings within each watershed were calculated and ranked against participation data by water activity. The Monongahela, Coal, and Cheat watersheds were perceived has having poor quality and poor recreation suitability. Fishing and swimming participation in those watersheds were in agreement with perceived quality and suitability. Boating participation stayed relatively high even though conditions were perceived as poor. Surprisingly, swimming participation was higher than fishing participation in perceived low quality watersheds. The Greenbrier, Gauley, and Elk watersheds were perceived as having excellent water quality and suitability. The Cacapon watershed differed in rank based on water quality and suitability perception. The Cacapon was perceived has having better water quality, but had a poor suitability rating. 
A.)

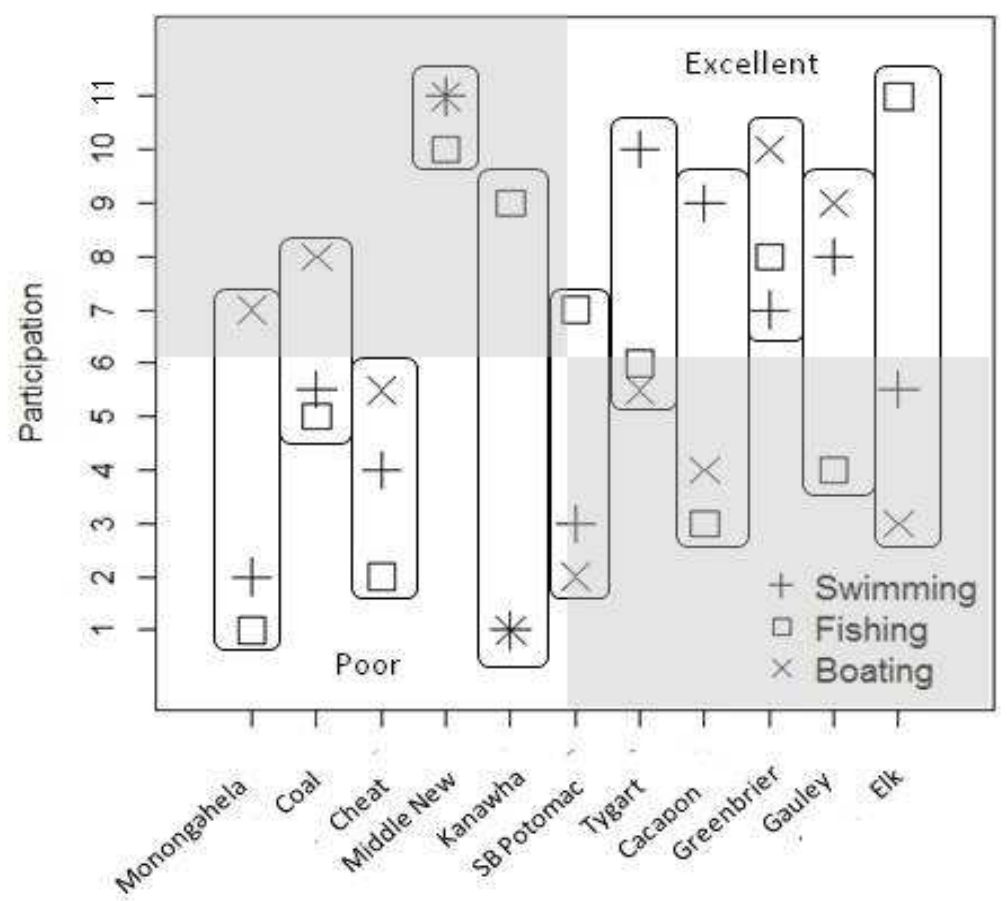

Watersheds Ranked by Water Quality Perception
B.)

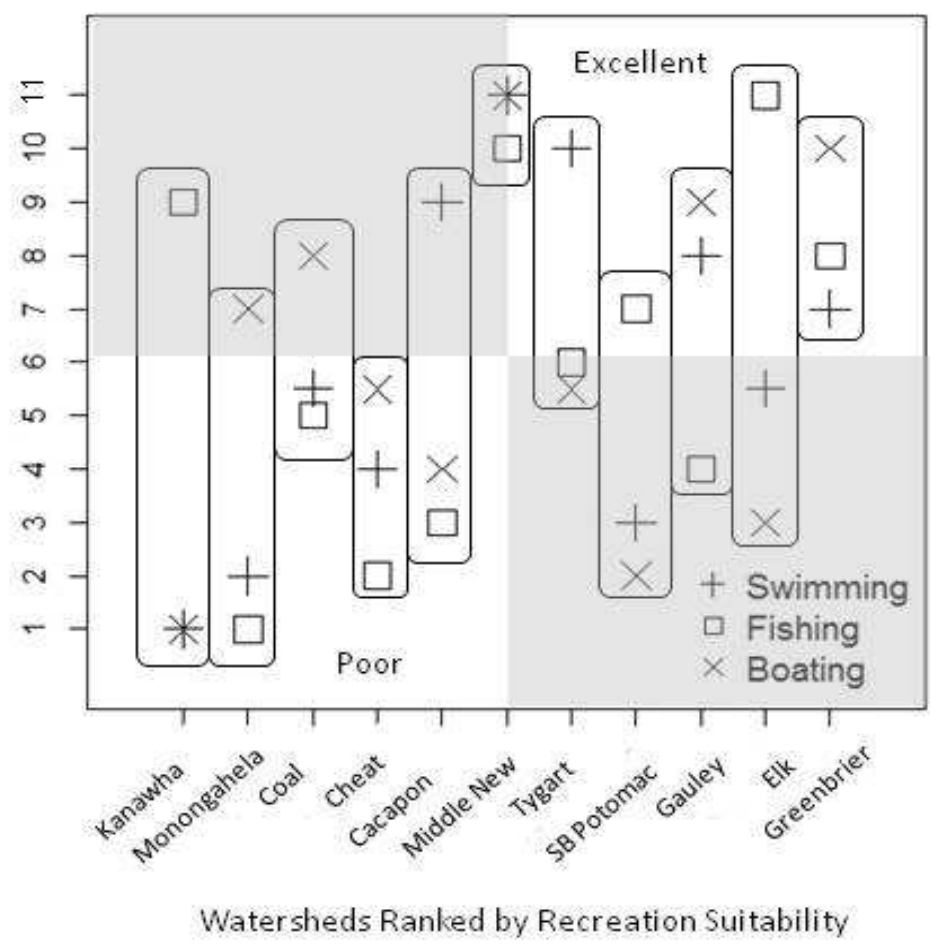

Figure 5. Distributions of Swimming, fishing, and boating activities ranked against A) water quality and B) suitability perceptions by watershed. Watersheds are ordered by mean perception ratings and are ranked from poor to excellent. Shaded areas represent areas of disagreement between perception and participation. 
The Tygart Valley, Gauley, and Elk watersheds were perceived as having both good water quality and good suitability. Tygart Valley had high participation in swimming and fishing but not boating activities. The Gauley had high participation in swimming and boating but not fishing. The Elk had high fishing participation but low swimming and boating participation.

The Middle New watershed had high participation across all activity types even though it was perceived as having poor water quality and poor suitability. The Cheat watershed had low participation and was perceived as having poor suitability but good water quality. The Greenbrier watershed was perceived as having good water quality and good suitability and had high participation in all activity types.

In summary, participation among swimming, fishing, and boating activities and perceptions of water quality and suitability of watersheds varied. Watersheds perceived as having good water quality did not necessarily have high participation among activity types. For example, the Elk River was perceived as having the best water quality and had high fishing participation. However, the Elk River did not have high participation in boating and swimming activities. There may be other factors contributing to water recreation participation besides its perception of water quality and recreation suitability.

Water Quality \& Suitability Perceptions between Activities- Mean perceptions of overall water quality and overall suitability for each activity type was compared on a river segment level $(n=41)$ to determine if the perception of water quality and suitability differed based on activity. Water quality and suitability perceptions were significantly different between activities and between river segments (Table 11.). Water quality in relation to swimming is generally rated lower than water quality in relation to fishing. This suggests that respondents perceive 
water quality differently particularly between swimming and fishing activities. The perception of suitability in relation to activity type was not significantly different within the post hoc test, but significant differences did occur from the ANOVA test $(p=0.04)$.

Table 11. ANOVA results between A).mean perceptions of water quality and B).mean perceptions of suitability by activity type across all river segments.

ANOVA

\begin{tabular}{|c|c|c|c|c|c|c|}
\hline Source of Variation & SS & $d f$ & $M S$ & $F$ & P-value & F crit \\
\hline River Segment & 47.28644 & 40 & 1.182161 & 6.773651 & $2.44 \mathrm{E}-13$ & 1.544887 \\
\hline MeanWQ & 4.62459 & 2 & 2.312295 & 13.24919 & 1.07E-05 & 3.110766 \\
\hline Error & 13.96188 & 80 & 0.174523 & & & \\
\hline Total & 65.87291 & 122 & & & & \\
\hline
\end{tabular}

ANOVA

B).

\begin{tabular}{lrrrrrc}
\hline Source of Variation & \multicolumn{1}{c}{ SS } & \multicolumn{1}{c}{$d f$} & $M S$ & \multicolumn{1}{c}{ M } & P-value & F crit \\
\hline River Segment & 40.43888 & 40 & 1.010971902 & 3.27575584 & $3.18 \mathrm{E}-06$ & 1.544887 \\
MeanSuit & 2.032733 & 2 & 1.016366546 & 3.293235592 & 0.042228 & 3.110766 \\
Error & 24.6898 & 80 & 0.308622483 & & & \\
& & & & & & \\
Total & 67.16141 & 122 & & & & \\
\hline
\end{tabular}

Relationships between perceptions and biological condition

Perceptions of Recreation Quality and Fishery Assemblage Data-Fish metrics were

compared to swimming, fishing, and boating composite scores by ranked scatterplots. River

segments were separated into two categories, wadeable \& large river, due to differences in

sampling effort. Perceptions of swimming quality were compared to the total intolerant

benthic species richness, percent intolerant species, and percent of invertivore/piscivore.

Fishing and boating quality were compared to conservative game abundance (Figure 6) and

total species richness. Ranked swim quality perception was significantly correlated with ranked 
percent intolerant species ( $p$-value $=0.01$, rho $=0.52$ ) and intolerant benthic species richness $(p$ value $=0.02$, rho $=0.51$ ) for wadeable streams but not for large rivers. Those three variables were the only comparisons that were found to have a correlation. Overall, perceived quality and suitability by activity type were not associated with fish assemblage data.

Nevertheless, there were 10 wadeable stream segments where perceived swim quality and fish metrics were in agreement. The Upper Blackwater, Cranberry, North Fork of the South Branch Potomac, Muddy Creek, Right Fork Buckhannon, and the Upper Elk were always considered good swimming and high in intolerant species, intolerant benthic species, and high in percent invertivore/piscivore. Wadeable sites that were always in agreement for poor swim quality and low fish numbers were Spruce Fork, Pond Fork, Dunkard Creek, and Pocatalico River. There were no large river sites that were in agreement over all three fish metrics that were compared to swim quality. The disagreement could be due to a combination of sampling error of large rivers and bias among perceptions of swim quality.

Although there was no correlation between boatable/fishable perception and conservative game abundance, interpretable patterns were evident (Figure 6). There are six river sites that were in agreement for both boating and fishing quality compared to species richness and conservative game abundance. The South Branch Potomac and lower Elk River were both ranked as having high boating and fishing quality and had high game abundance and species richness. Big Sandy Creek and lower Bluestone River were ranked as having poor boating and fishing quality with poor game abundance and species richness. Of the wadeable segments Muddy Creek was considered good in both perception and fishery data. Pond Fork 
and Three Forks were ranked low in all four categories (poor fishing/boating and poor
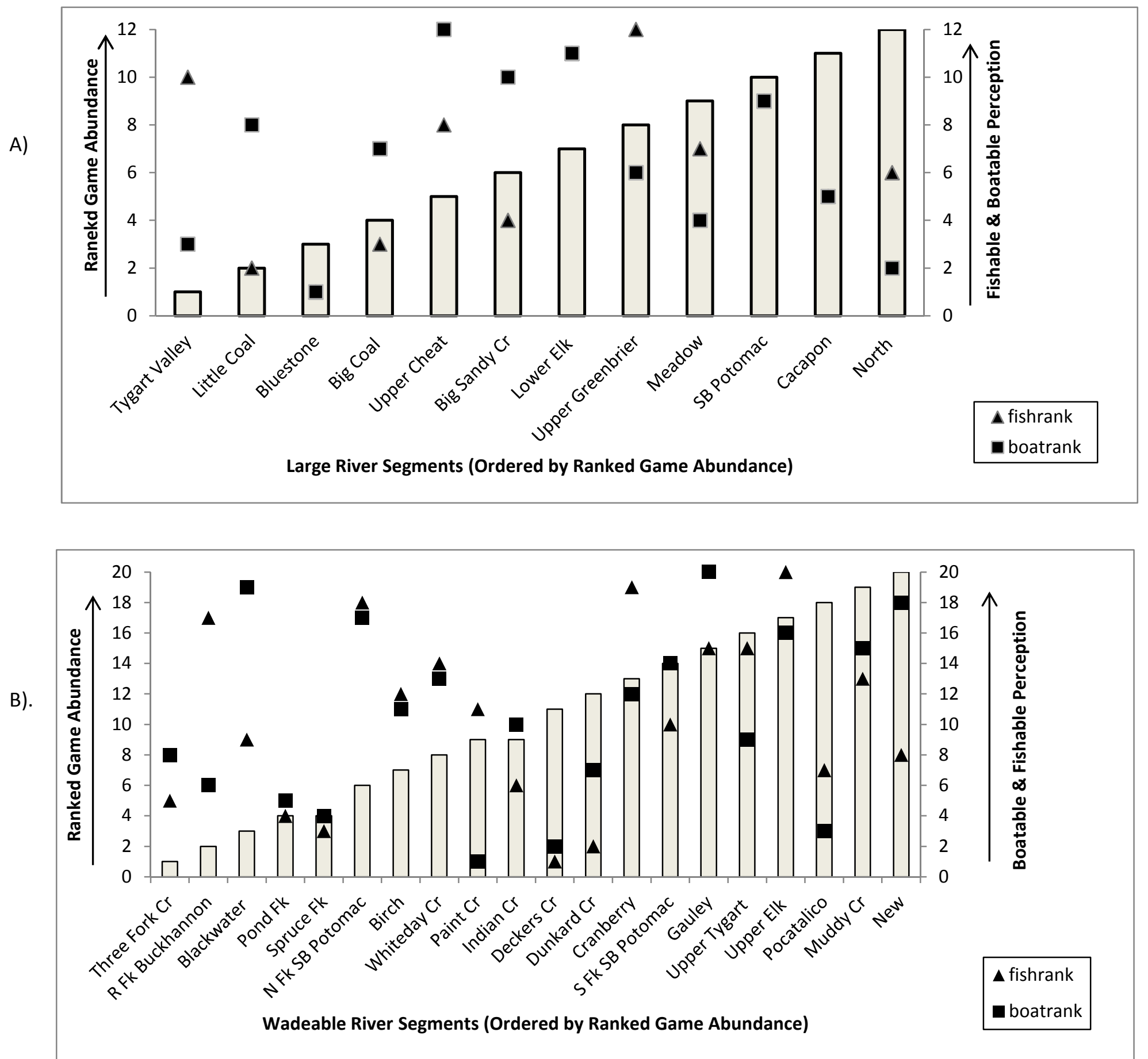

abundance and richness). 
Figure 6. Ranked conservative game abundance by A). large river and B). wadeable river segments. Ranked fishable and boatable perceptions are expressed for each river segment. Ranks are ordered from poor to excellent condition.

Impairment-A river is determined impaired if it does not meet its water quality standards and violates its designated uses (WVDEP 2010). Within the study area a total of twenty-six river segments have been listed as impaired within the 2010 and 2012(Draft) WVDEP Integrated Water Quality Monitoring and Assessment Report (WVDEP, 2010, 2012). Nine sources contributing to the impaired river segments included: fecal coliform, iron, aluminum, CNA (conditions not allowable)-biological, algae, $\mathrm{PCB}$ 's, $\mathrm{pH}$, selenium, and dissolved oxygen (Table 12.). Sixteen of the surveyed river segments are listed as impaired by only one source (Table 13.). Lower Muddy Creek within the Cheat watershed was the only river segment listed by five different sources of impairment. The least common source of impairment within the study area was dissolved oxygen (Figure 7.). The majority of those impaired are exceeding the monthly geometric mean of 200 counts $/ 100 \mathrm{ml}$ or exceeding 400 counts $/ 100 \mathrm{ml}$ in more than $10 \%$ of the monthly samples of fecal coliform material (WVDEP, 2010). Iron was also a major contributing source of impairment within the study area. 
Table 12. Surveyed river segments that are defined as impaired and not impaired. Segments that are impaired are categorized by source of impairment. Some segments are repeated due to more than one source of impairment.

\begin{tabular}{|c|c|c|c|c|c|c|c|c|c|}
\hline \multicolumn{10}{|c|}{ River Segments 303(d) Listed and Source of Impairment } \\
\hline \multirow{2}{*}{ Not Impaired } & \multicolumn{9}{|c|}{ Impaired } \\
\hline & Fecal Coliform & $\mathrm{Fe}$ & Al & CNA-Biological & Algal Blooms & PCB & $\mathrm{pH}$ & Se & DO \\
\hline U Elk & SB Potomac & Paint $\mathrm{Cr}$ & Three Forks $\mathrm{Cr}$ & L Spruce Fk & L Greenbrier & SB Potomac & Big Sandy $\mathrm{Cr}$ & L Spruce Fk & Deckers $\mathrm{Cr}$ \\
\hline Gauley & Tygart & White day $\mathrm{Cr}$ & Cranberry & Birch & SB Potomac & Kanawha Falls & Lower Muddy Cr & Big Coal & \\
\hline Indian $\mathrm{Cr}$ & Meadow & LCheat & L Muddy Cr & Big Sandy $\mathrm{Cr}$ & Cacapon & Winfield Locks & L NF Blackwater & Birch & \\
\hline U Greenbrier & Kanawha Falls & Lower Muddy & U Blackwater & Lower Muddy & & L Bluestone & & & \\
\hline Muddy $\mathrm{Cr}$ & Monongahela & L NF Blackwater & L NF Blackwater & Pocatalico & & & & & \\
\hline New & Deckers $\mathrm{Cr}$ & Birch & & & & & & & \\
\hline North Fk & Big Sandy $\mathrm{Cr}$ & Pocatalico & & & & & & & \\
\hline North & Lower Muddy & LElk & & & & & & & \\
\hline Trout Rn & Birch & & & & & & & & \\
\hline Pond Fk & Pocatalico & & & & & & & & \\
\hline U Cheat & U Tygart & & & & & & & & \\
\hline Little Coal & L Tygart & & & & & & & & \\
\hline Dunkard & LElk & & & & & & & & \\
\hline South Fk & & & & & & & & & \\
\hline RF Buckhannon & & & & & & & & & \\
\hline
\end{tabular}


Table 13. Each surveyed river segment and its total number of impairment sources. Table is sorted by the least number of impairment sources to the most number of impairments.

\begin{tabular}{|c|c|}
\hline River Segment & Number of Impairment Sources \\
\hline Dunkard & 0 \\
\hline Gauley & 0 \\
\hline Indian Creek & 0 \\
\hline Little Coal & 0 \\
\hline Muddy Creek & 0 \\
\hline New River & 0 \\
\hline North Fork & 0 \\
\hline North River & 0 \\
\hline Pond Fork & 0 \\
\hline RF Buckhannon & 0 \\
\hline South Fork & 0 \\
\hline Trout Run & 0 \\
\hline Upper Cheat & 0 \\
\hline Upper Elk & 0 \\
\hline Upper Greenbrier & 0 \\
\hline Big Coal & 1 \\
\hline Cacapon & 1 \\
\hline Cranberry & 1 \\
\hline Lower Bluestone & 1 \\
\hline Lower Cheat & 1 \\
\hline Lower Greenbrier & 1 \\
\hline Lower Ty & 1 \\
\hline Meadow & 1 \\
\hline Monongahela & 1 \\
\hline Paint Creek & 1 \\
\hline Three Forks & 1 \\
\hline Tygart & 1 \\
\hline Upper Blackwater & 1 \\
\hline Upper Ty & 1 \\
\hline White Day & 1 \\
\hline Winfield Locks & 1 \\
\hline Deckers & 2 \\
\hline Kanawha Falls & 2 \\
\hline Lower Elk & 2 \\
\hline Lower Spruce Fk & 2 \\
\hline Lower NF Blackwater & 3 \\
\hline Pocatalico & 3 \\
\hline South Branch Potomac & 3 \\
\hline Big Sandy & 4 \\
\hline Birch & 4 \\
\hline Lower Muddy & 5 \\
\hline
\end{tabular}




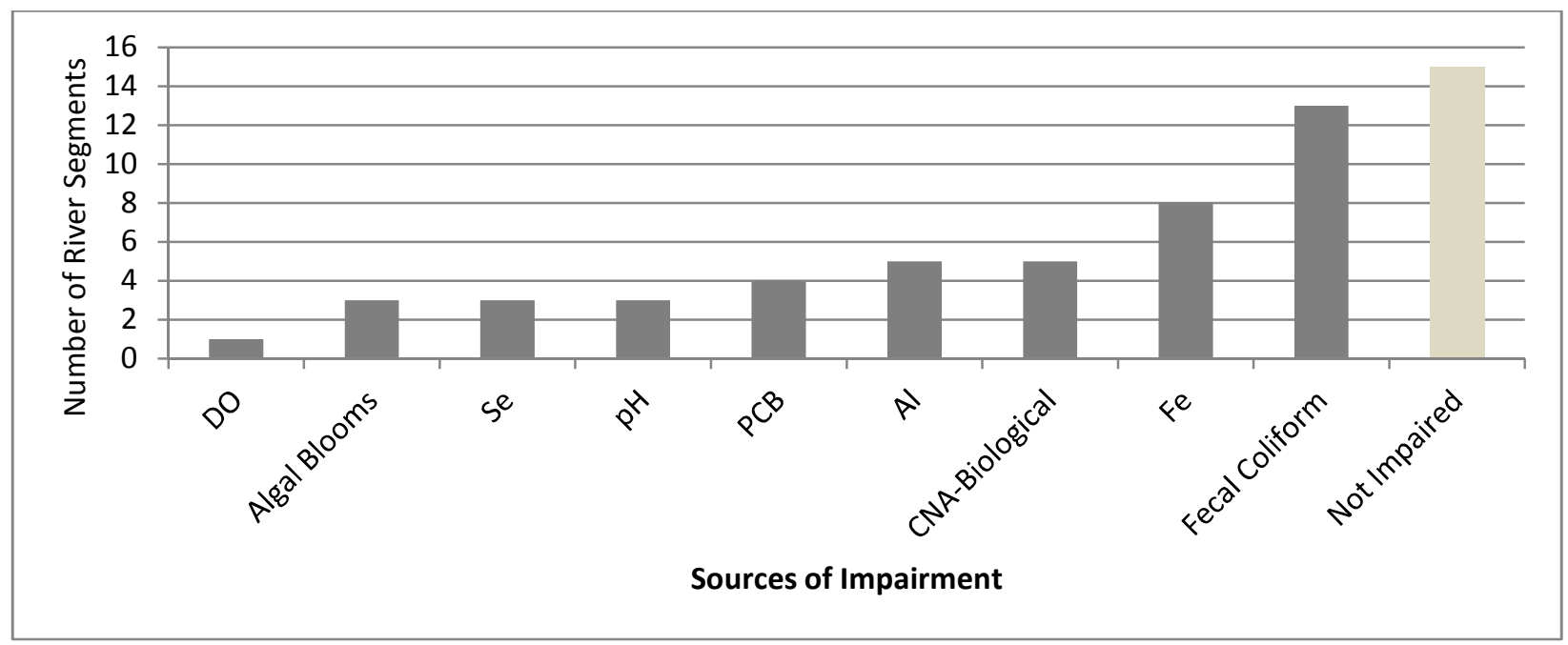

Figure 7. Number of surveyed river segments within each type of impairment source. CNAbiological refers to conditions not allowable.

\section{Perceptions of Water Quality and Suitability by Impairment Source-The mean}

perceptions of suitability and water quality were calculated for each source of impairment to determine which types of impairment respondents perceive as poor in relation to other sources. Mean ratings were scaled from 1-5, 1 being poor, 5 being excellent. Dissolved oxygen and $\mathrm{pH}$ sources had the lowest water quality and suitability scores and algae had the highest rating for both types of perceptions (Figure 8.). Sources of algae impairment were rated as more suitable and as having better water quality than not impaired river segments. Mean perceptions of suitability and water quality varied by aluminum impaired sites, but perceptions between suitability and water quality were not statistically different based upon impairment source ( $p$-value $=0.18)$. 
A).

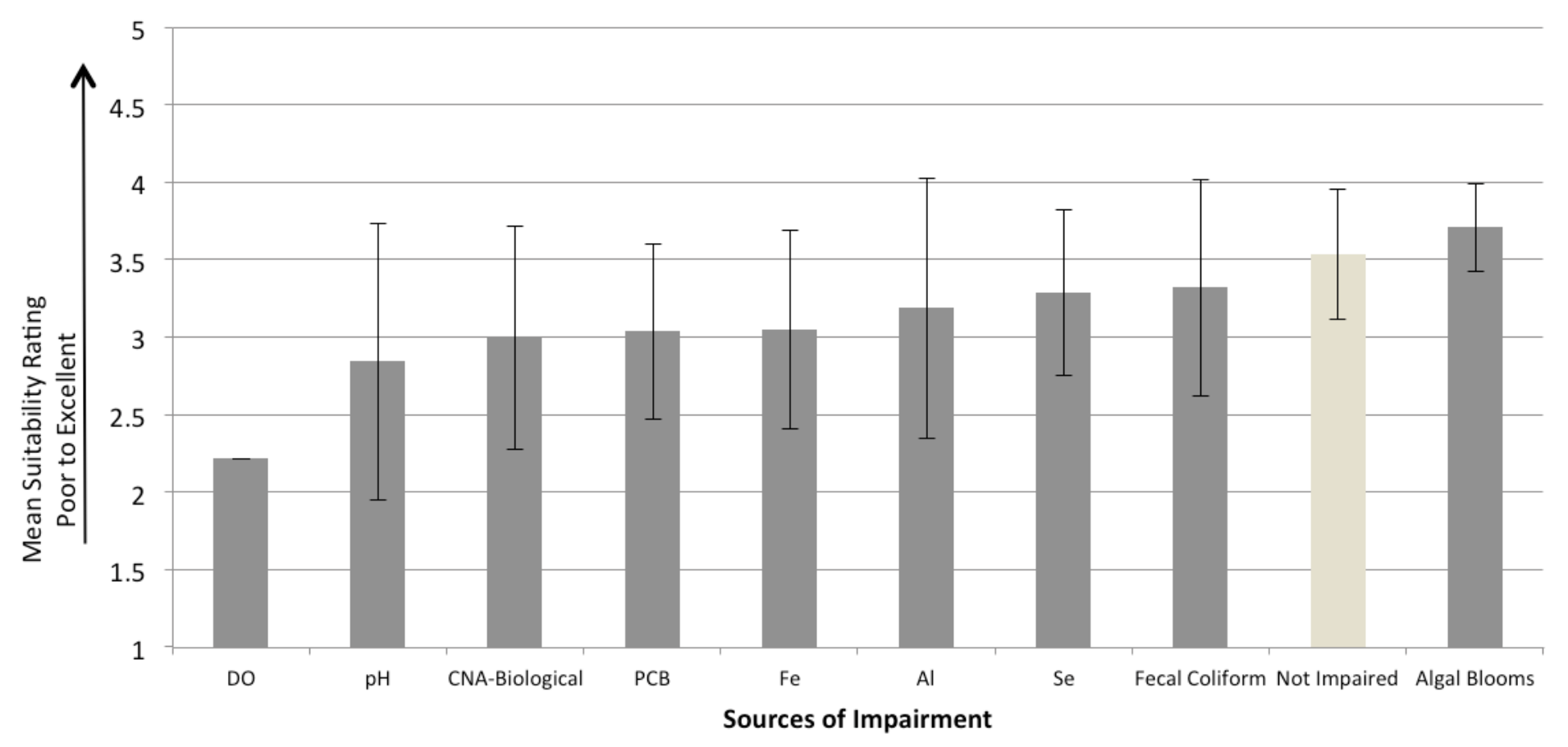

B).

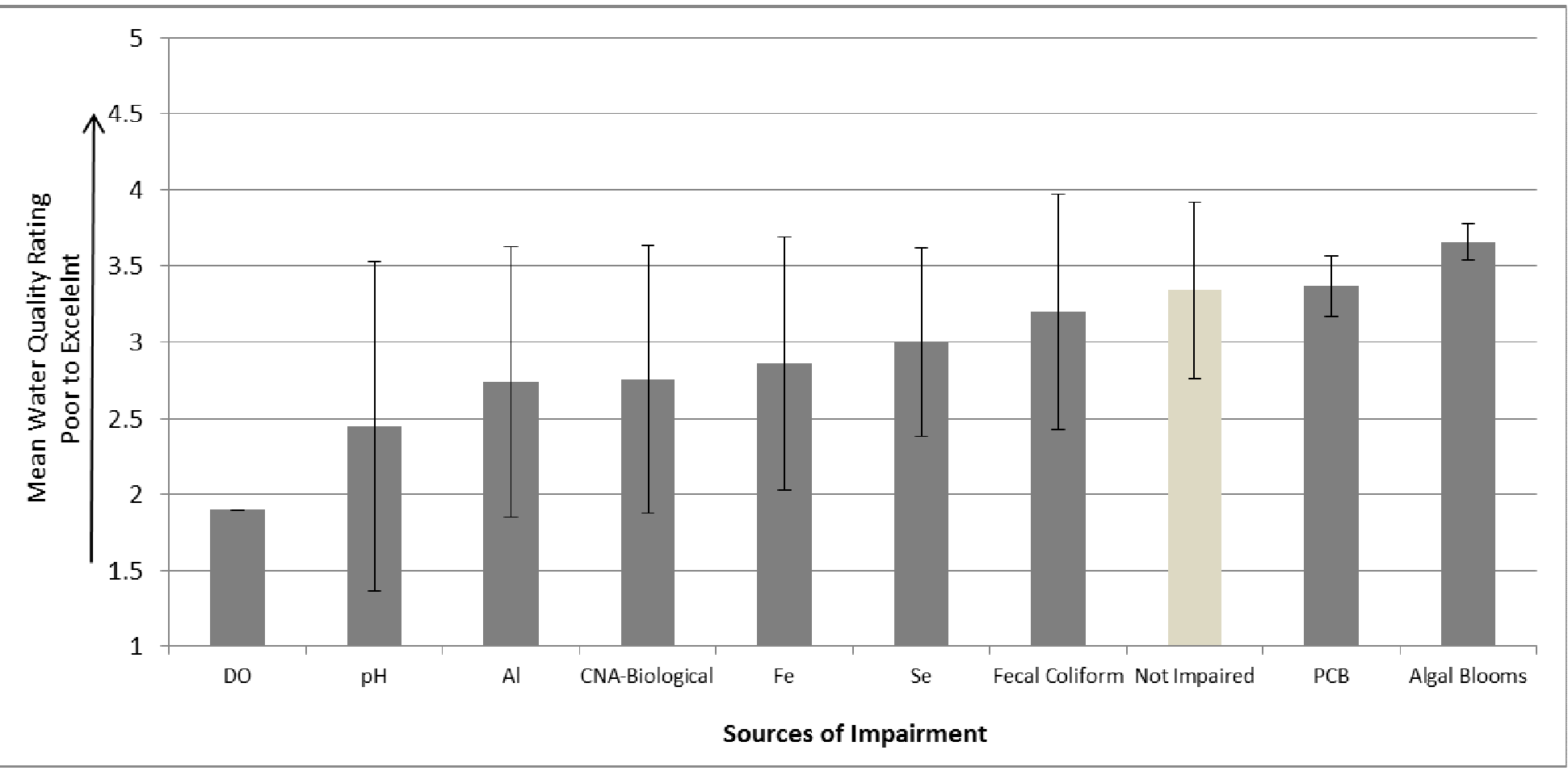

Figure 8. A). mean suitability and B). mean water quality perceptions by impairment source. 

impairment had an effect on perceptions of suitability by activity, impaired and not impaired sites were compared (Figure 9.). Mean suitability rating for each river segment and each activity type was scaled from 1-5, 1 being poor and 5 being excellent. Impairment does not seem to be a factor of perceived suitability for swimming, fishing, or boating. Lower Muddy Creek was listed as the only segment with five impairment sources and was perceived as having the worst overall suitability for all activities. With the exception of Lower Muddy Creek, suitability perception was not affected by the number of impairment sources. In general, perceptions of swimming suitability were rated low and the perceptions of fishing suitability were rated as high across all river segments. 


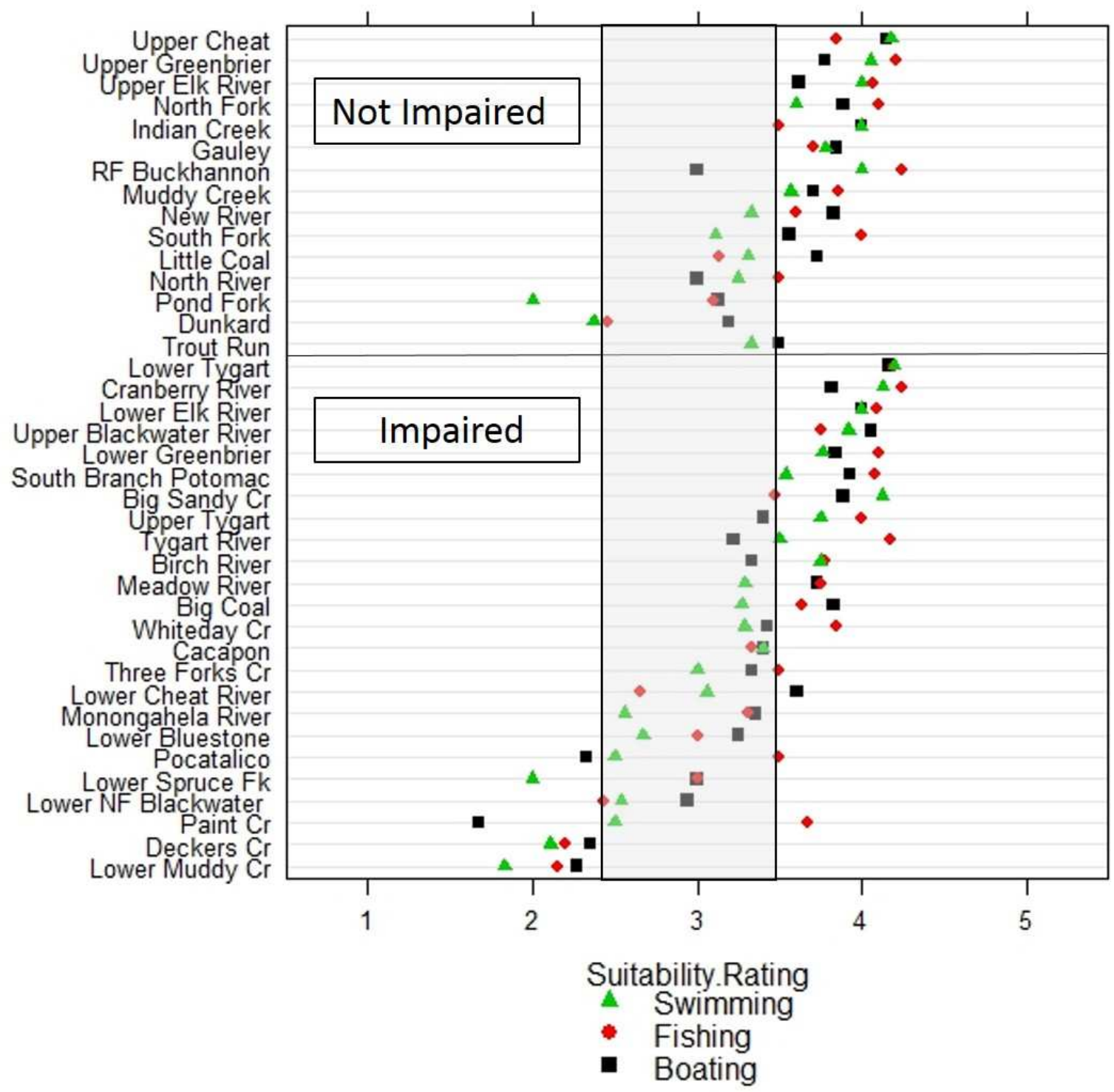

Figure 9. Dot plot of mean suitability ratings for swimming, fishing, and boating by river segment. River segments are grouped by impaired and not impaired segments. Suitability is scaled from 1-5, one "being recreation is nearly impossible because of the biological condition" and five being "beautiful, could not be any nicer". The grey zone represents sites and activities considered slightly impaired because of the biological condition. 


\section{Perception of Water Quality by Activity of Impaired and Not Impaired River Segments-}

Perceptions of water quality between fishing and boating activities were not significantly different $(p$-value $=0.31)$ determined by a two sample $t$-test assuming unequal variance. Fishing and boating scores were double weighted and ranked against the perception of water quality as it relates to swimming. Ranks were scaled from 1-39, 1 being perceived as the worst river segment and 39 being perceived as the best river segment. The majority of river segments were in agreement about water quality as it relates to swimming, fishing, and boating (Figure 10). Impaired sites were perceived as both good and poor water quality across all activity types. Impairment was not a factor of water quality perception. Eight river segments were ranked differently between activity types as it relates to water perception. Little Coal River, New River, and Meadow River were perceived as poor water quality for swimming but good water quality for fishing and boating. The Upper Tygart River, Right Fork Buckhannon River, Birch River, Bluestone River, and Trout Run were perceived as good water quality for swimming but poor quality for fishing and boating. 


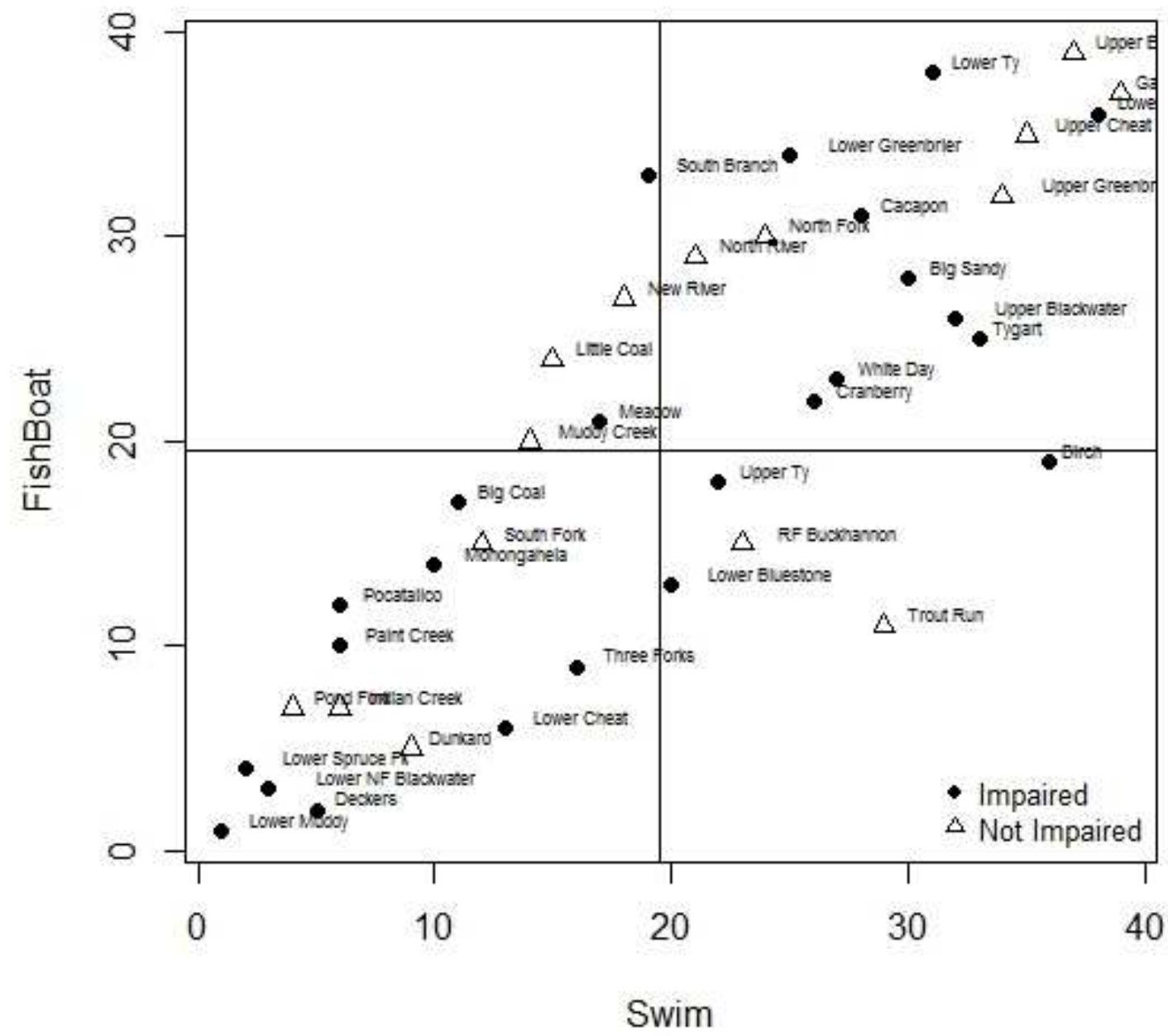

Figure 10. Scatterplot of the perception of water quality by activity (fishing \& boating compared to swimming). River segments are grouped by impaired and not impaired water bodies. The plot is ranked from poor to excellent. 
Spatial patterns of user perceptions

Spatially Clustered Perceptions- Environmental stressors, suitability scores by activity and activity composite scores were used to test if perceptions are clustered based upon geographic location within the state of West Virginia. Environmental stressors included mine drainage, litter, sewage, erosion, acid precipitation, agricultural runoff, storm water runoff, and fracking flowback water. Respondents were asked to rate the most important and least important stressor concerns for each river segment on a scale of 1-5, five being least important. The Global Moran's test of significance was used in ArcMap version 10 to determine if perceptions of environmental stressors were clustered based upon region. All stress variables were deemed not significant and determined random. Suitability and composite scores of swimming and boating were not significant and considered random. Fishing suitability and fish composite scores were the only two variables tested that were determined as dispersed rather than having a random distribution. This suggests that respondents are not making a generalization about a particular region's water quality and water recreation suitability. 
CHAPTER FIVE

\section{DISCUSSION}

Recreational Users of West Virginia

Recreation data is obtained every five years through the National Survey on Recreation and the Environment (NSRE) and the annual national survey administered for the Recreation Roundtable (Kakoyannis \& Stankey, 2002). The NSRE provides an opportunity to analyze long term trends in outdoor recreation participation and personal demographics. Unfortunately, uncertainty in sampling methods makes it difficult to view trends consistently over time (Cordell et al., 2009). Recreation use on a national scale can obscure differences among various regions. Consequently, data on recreation use should be analyzed on a smaller scale. In addition to the NRSE, each state compiles a Statewide Comprehensive Outdoor Recreation Plan (SCORP) which often includes water-based recreation participation.

West Virginia's SCORP plan provides federal funding of outdoor recreational development through the Land and Water Conservation Fund (LWCF)(WV Dept. of Commerce 2013) The most recent SCORP plan was submitted for the 2009-2013 cycle and describes the needs of outdoor recreation and their relationship to public health and community development (WV Department of Commerce, 2013). The SCORP plan compares demographics by age class, education level, income level, and grouped by geographic region. The survey provides general information and asks questions such as how active are you, recreation frequency by activity, and favorite recreation location. Swimming, fishing, and boating activities are listed, however, fishing is joined with hunting activities and canoeing is listed in the same category as camping. 
Swimming, fishing, and boating activities have been shown to be the most widely conducted outdoor recreational activities within the United States (Kakoyannis \& Stankey, 2002) and should be analyzed separately from other categories. Water dependent activities should be surveyed individually particularly for water resource management. Water dependent recreationists respond differently to changes in site and water quality characteristics (Forster, 1989). For example, a user may boat the Cheat River, but not fish the river due to biological condition. Water-based participation can identify activity specific recreational demand as well as provide information on areas of perceived good and poor river condition. WV SCORP asks respondents where their favorite places are to recreate by municipality. Grouping by municipality is ideal for community development and any public health concerns, but it is not appropriate for managing water resources. If the goals are to identify recreational demand, ecotourism opportunities, and promote riverine conservation planning, locations of recreation should be grouped by river or by watershed.

Water recreational users were asked various socio-demographic questions pertaining to gender, age, residency, watershed organization involvement, water-based activity participation, the average number of fish caught within a given fishing trip, and the average number of kilometers traveled to recreate within a given watershed. Statistical differences in demographic variables did occur across watersheds with the exception of watershed organization membership and residency (Table 5).

A statistical difference in watershed organization membership was expected due to variations in survey responses across watersheds. Differences did occur with the Cheat and 
Monongahela watersheds having the highest number of respondents associated with a watershed organization ( $73 \%$ \& 65\%, respectively). The Cheat and Monongahela watersheds also had the largest number of overall responses. Similarly, the Kanawha watershed had the lowest watershed organization involvement and had the lowest number of respondents once the Tug and Upper Guyandotte watersheds were removed. Differences could be due to our variation in sample sizes between watersheds. It could also be due to the influence of our sampling technique using a web-based survey and targeting watershed and recreational outfitter organizations.

We suggest, within our study, that watershed location has an effect on recreational user demographics although statistical differences should be considered with caution due to small and unequal sample sizes. Planning and prioritizing on a watershed scale can reveal and describe biological, physical, and socio-economical resources across the landscape (Bohn et al., 2002). Contrastingly, watersheds have been shown to rarely coincide with any units of the social landscape (Rhoades, 1998; Guijt \& Sidersky, 1999; Johnson, 2002). Ethnic groups, political boundaries, religious grounds, preservation parks, and individual farms do not overlay watersheds. Rhoades (1998) suggests combining watershed with participation for potential planning, prioritizing, and development projects rather than trying to target socio-demographic groups.

Recreational users were asked how far they were willing to travel in order to recreate within each surveyed watershed (Table 6). Typically, distance questions are related to travel costs and ultimately economic valuation studies (Loomis et al., 2000; Richardson et al., 2006; 
Viscusi et al., 2008). Variation in visitor travel costs can be used to model a recreation demand curve for each site location. Based on the recreation demand curve, consumer surplus of water recreation with improved water quality can be estimated (Loomis et al., 2000). For this study, we did not choose to look at the economic value of each river segment or watershed however, we did want to explore a users' willingness to travel for recreation within the state.

Since the majority of respondents were residents, most locations in West Virginia can be reached in less than 515 kilometers of travel. Due to geographic size, outliers over $483 \mathrm{~km}$ (300mi) were removed. Across all surveyed watersheds the mean distance traveled ranged from 30-195 km (19-120miles). River recreationists were willing to travel more than $160 \mathrm{~km}$ (100mi) to reach the middle New and upper Guyandotte watersheds. The middle New watershed had the highest overall activity participation (Table 10). Within the Kanawha and Monongahela watersheds, recreationists were the least willing to travel; the mean travel distance was less than $33 \mathrm{~km}(20 \mathrm{mi})$. This could be a result of both watersheds having large rivers, high commercial traffic, and low recreation opportunity, or it could be a response based on urban density. Two of the largest urban centers in West Virginia, Morgantown and Charleston, reside in watersheds with the lowest willingness to travel. Nearby residents would not need to travel far to reach rivers within those watersheds in order to recreate. The Greenbrier, Gauley, Cacapon, and Tygart Valley watersheds had high maximum travel distance $(>400 \mathrm{~km})$ and large variation between values $(>385 \mathrm{~km})$. The Gauley, Cacapon, and Tygart all had sample sizes less than 30 which may affect the large variation in distance traveled. The Greenbrier had the second highest overall activity participation following the middle New. 
With a large variation in travel distance and a high participation response, its' suggested that the Greenbrier watershed has the highest recreation demand within our study area.

Distance has been a significant determinant in visitation rates and in contingent valuation models (Richardson et al., 2006). Respondents were asked, on average, how many days per year they spend fishing, swimming, and boating within the surveyed river segments. The majority of respondents selected 0 days spent per year on water recreation. Contrastingly, respondents were willing to respond to questions related to participation and travel distance. We were unable to analyze visitation patterns further due to the skewed respondent data. Richardson et al. (2006) found in-state visitors to gain higher benefits because of greater trip frequency. They compared long-distance and short-distance visitors and found short-distance visitors to be more affected by variations in climate and park resources. He also concluded that short-distance visitors were more likely to take day trips (average stay of 1.3 days). As resource managers, changes in visitor behavior can have an effect on park management and local economic activity (i.e. travel expenses per trip). Based from our sample population, $86 \%$ of water recreationists were residents. Future studies should be conducted in West Virginia to determine if water recreationists are being affected similarly to the findings of Richardson et al. (2006).

Creel surveys estimate angler effort, fish harvest (Pollock et al., 1994), and address concerns regarding recreational fisheries and angler populations (Soupir et al., 2006). It was not our intention to conduct a creel survey but we did want to examine how many fish are being caught in a typical fishing day per watershed (Figure 4). The main purpose was to 
identify large variations in angler effort by watershed. The mean number of fish caught in a given trip ranged from one to twenty fishes caught. Responses for the Cheat watershed were most consistent reporting catching 1-2 fish in a typical day $(n=31)$. The middle New, Greenbrier, and Coal watersheds expressed the highest variability.

Recreationists that fished only within the last two years were asked what species they were fishing for and in which river segments. Unfortunately, based on our sample design respondents did not declare which river segments they were fishing from. In absence of data, targeted species were categorized and grouped together by watershed rather than by river segment. Over the entire study area, anglers are mostly fishing for bass $(n=122)$ and trout species ( $n=74)$. Fishing for trout was present across all watersheds (mostly due to stocking efforts). The Greenbrier $(n=25)$ and the Monongahela $(n=24)$ had the highest number of anglers who provided species information. Based on the WV 2013 fishing regulations summary, favorite fishing waters included: Kanawha, New, South Branch of the Potomac, Elk, Gauley, Monongahela, Cheat, Cacapon, and Greenbrier Rivers (West Virginia Fishing Regulations, 2013). WVDNR suggests trout fishing in the Elk, South Branch of the Potomac and tributaries of the Cheat River are favorite waters in the state. The Cheat and Elk watersheds had a high number of respondents who said they were fishing for trout species. However, only a little over half of the respondents said they were fishing for trout within the South Branch.

The Cacapon, Elk, Greenbrier, New, and South Branch Potomac rivers are suggested for favorite waters in smallmouth bass fishing (WVDNR, 2013). Our sample is in agreement with WVDNR's favorite waters regarding bass fishing. Bass Anglers were present across all 
watersheds. Interestingly, one paddlefish (Polyodontidae) and Mooneye (Hiodontidae) were claimed to have been hooked in the Kanawha watershed. Gars were also notably fished in the Monongahela and Kanawha mainstems. Bass species were predominately targeted over trout species. Due to the survey design and small sample size no definite conclusions can be made suggesting that bass species are being fished more than trout species, but qualitatively the data could be used in further understanding angler populations and angler effort.

\section{Study Area Socio-Demographics}

Based on our study area, the majority of recreational users were male (77\%) and West Virginia residents (86\%) (Table 9). The average age was 45 years old with a mode of 29 years old. The median age of 44 years old was slightly higher than the state's median age of 41.3 years (U.S. Census Bureau, 2010 Census). Over half of all respondents said they have participated in swimming (54\%), fishing (64\%), and boating (68\%) activities within the state. Water recreation respondents in the study area participated more in swimming, fishing, and boating activities than the national number of respondents in a 2009 study (Cordell et al., 2009). According to the National Survey on Recreation and the Environment (NSRE), $12.4 \%$ of total participants canoed or kayaked, $33.8 \%$ fished, $23.3 \%$ motor boated, $35.6 \%$ boated, and $40.7 \%$ of total respondents said they went swimming in lakes, streams, etc. between the years of 2005 and 2009 (Cordell et al., 2009). This study suggests that West Virginia has a higher water-based activity participation compared to the national average. 


\section{Activity Participation}

Water recreationists and rivers are intimately interconnected and changes to one or the other can have important consequences in recreation opportunities and habitat degradation. Water levels and dam releases have an effect on water-based recreation and habitat degradation can be a source of crowding causing riparian damage and recreational dissatisfaction (Kakoyannis \& Stankey, 2002). If overcrowding occurs, recreationists can be displaced to different locations or may change their activity altogether (Robertson \& Colletti, 1994). Manning (1999) refers to the latter as recreation substitutability, a circumstance of over-crowding in which recreationists modify their activity. Demand for a particular water body may ultimately be reduced, affecting management and potentially affecting any participatory environmental efforts. If users are displaced it can also potentially cause conflict in other locations. If water resource management continue to take an ecosystem approach or focus on watersheds as analysis units, it is fundamental to know where and what activities people are participating in to prepare and anticipate future recreation demand or lack thereof.

Across the entire study area, activity participation was evenly distributed between the three most common water-based activities and varied by watershed. The Middle New watershed had the highest amount of participation overall and the Monongahela watershed had the lowest participation overall (Table 10). An outdoor recreation resource amenity index developed for WV by Wang (2008) found nature-based resources to be largely concentrated in the eastern region of the state around Pocahontas County. He also found Summers County to rate high in water resources due to relatively long river lengths within that county. The Middle 
New and Greenbrier watersheds had the highest overall participation; both watersheds contain Summers and Pocahontas countries which scored high in Wang's amenity index. Our studies results are consistent with Wang (2008) findings.

The majority of respondents preferred fishing and boating over swimming activities. Swimming participation was the most variable activity across watersheds ranging from $0-83 \%$ participation. The variability may be due to the fact that people are unlikely to swim in a water body they find aesthetically unappealing. David (1971) found $80 \%$ of respondents would not go swimming if algae were present. A more recent study found that fishing, boating, and swimming activities are negatively affected by undesirable algae levels (Suplee et al., 2009). Several additional studies have determined that visual characteristics such as water clarity and color affect the public's acceptability of that water body and impacts recreation activities (David, 1971; Smith and Davies-Colley, 1992; Smith et al., 1995; Suplee et al., 2009).

A water quality ladder was developed as a use-based measure to describe water quality in an ascending scale from having no uses to being suitable for boating, fishing, and swimming in that order (Vaughan, 1986; Hime et al., 2009). We would expect to see only high boating participation in areas of low quality. As perception of water quality increases, overall participation would increase. Boat participation follows a decreasing trend as perceived water quality and suitability increases. Boating participation was high when water quality was perceived as poor but participation, when water quality is perceived as excellent, did not have high participation across all activities. Boating participation was low in areas perceived as excellent water quality. The South Branch Potomac, Tygart, Cacapon, and Elk Rivers were low in 
boating participation, but were perceived as excellent water quality. This could be due to drainage area, accessibility, or our small sample size. In contrast to boating participation, swimming participation generally increased as perception of water quality increased. The Tygart, Cacapon, Greenbrier, and Gauley Rivers were all high in swimming participation and high in perceived water quality. Fishing participation did not seem to have a pattern with regards to perception.

A study done on the Connecticut River identified public perception of quality as a critical indicator of success in restoration and protection of important recreational resources (Mullens \& Bristow, 2003). Perceived quality had the most influence on recreational demand and enjoyment rather than the actual quality. Although there were no correlations between activity participation and perception, we tested if participation was a function of perception through simple linear regression. Participation was transformed into arcsine values, respectfully. Activity participation was not dependent on perceived condition. Recreational users are still participating in water activities where they perceive the water quality and suitability to be in poor condition in relation to other watersheds in the state. There may be other influences affecting a person's decision to participate in water activities other than perceived quality. Crawford \& Godbey (1987) described three different types of constraints to leisure participation; interpersonal, intrapersonal, and structural constraints. Interpersonal constraints occur when there is a lack of persons to participate with. Intrapersonal constraints are barriers caused by personal preferences (e.g. stress, religion, anxiety, perceived self-skill, and social attitudes). Structural constraints include financial obligations, time away from work, age, and external factors such as season and climate. 
By recognizing the distributions of activity participation by watershed we determined if perceptions were significantly different based on recreation activity by river segment. With reference to the water quality ladder approach developed by Vaughan (1986), we hypothesized that respondents would be more likely to boat or fish rather than swim in a river segment due to perceived water quality and suitability ratings. Swimming is in direct conflict with commercial use (e.g., wastewater discharge) and is expected to have higher standards of acceptable quality (David, 1971). The number of sites suitable for swimming was expected to be lower than sites suitable for boating and fishing. Perceptions were significantly different between river segments and between activity types (Table 11). Tukey-Kramer tests with unequal sample sizes were used in post-hoc to determine where perceptions were different among activity type. Respondents perceive water quality in relation to swimming to be less acceptable than fishing quality. Consequently, we can accept our hypothesis of respondents being more likely to fish than swim in a river due to perceived water quality.

\section{Relationships between Perceptions and Biological Condition}

The importance of local knowledge in the field of resource management has been emphasized for decades (Johannes, 1978; Dahl, 1989; Mackinson, 2001), but barriers still exist with incorporating user survey data with physical, chemical, and biological data (Mackinson, 2001). Perceptions and local values can provide a cultural and historical context as well as provide a way of identifying knowledge gaps in watershed management. Perceived river condition for fishing or boating activities compared to measured fish data can tease out missing data or inaccurate perceptions. Biases are most likely incorporated into how a water body is perceived. Nevertheless, data on user perceptions can still provide valuable baseline 
information (Mackinson, 2001). Silvano \& Begossi (2005) analyzed local knowledge held by fishers and compared biological data on the fish species Pomatomus saltatrix (bluefish). They found differences and similarities between local information compared to ecological information of the bluefish. In conclusion, they suggest contributions of fishers' local knowledge can be used to improve scientific knowledge and promote cooperation between stakeholders and scientists. Hall-Arber et al., (2009) also arrived at the same conclusion suggesting collaboration between scientists and fishing participants is critical in ecological, economical, and social changes in management.

In this study, perceptions of river quality were not correlated with fishery assemblage data based on the spearman rank correlation test. Swim quality perception and intolerant benthic species richness were weakly correlated ( $\mathrm{rho}=0.51$ ) as well as swim quality and percent intolerant species (rho=0.51) for wadeable streams only. We expected to see a linear pattern among conservative game abundance and the perception of fishable and boatable river segments. Ideally, as game abundance increases, river segments increase in fish and boat quality. Mean ratings for water quality and suitability perception were compiled for a better perception representation and ranked among wadable and large river segments. By using a rank approach and comparing streams to each other in West Virginia, relative water quality impacts of individual drainages can be determined and remediation priorities can be validated (Stringfellow, 2008).

Overall, respondents had the tendency to over-perceive fishable/boatable quality with rivers of low game abundance (Figure 6). The observed disconnect between perception and 
fish data could be due to an incomplete fish dataset or fish sampling error. It could also be due to the survey design and unequal sample sizes; we did not ask respondents to rank rivers in order by most fishable or boatable. Perception of boat quality was $58 \%$ higher than fish quality in the large river segments and 55\% higher in the wadeable river segments. Meadow River, South Branch of the Potomac, Cacapon River, and the North River had the highest relative game abundance of the large river sites but were perceived as having low fishing and boating quality. Wadable river segments were more in agreement among ranked game abundance and perceived fishable/boatable quality than the large river sites.

\section{Stream Impairment and Perception}

Our study suggests that perceptions differ based on water recreation activity and based on river segment. We wanted to determine if respondents were also perceiving impaired versus non-impaired water bodies in the state of West Virginia by comparing impairment sources to mean ratings of perceived water quality and suitability. In our analysis, we expected non-impaired water bodies to have the highest perceived water quality and suitability ratings compared to impaired water bodies.

River segments impaired by algae had a higher mean rating for perceived suitability than non-impaired segments (Figure 8). Segments impaired by algae and PCB's had higher mean ratings for perceived water quality than non-impaired sites. Perceptions varied between water quality and suitability by impairment source but were not statistically different ( $p$-value=0.18) Sites defined as impaired did not have an effect on perceived condition. It's been shown that perceptions of water clarity and color have a strong influence on site suitability rating (Smith et 
al., 1995). However, waters impaired by algae were rated as most suitable and had a higher water quality rating than waters not impaired. Smith et al., (1995) found that people's ranking of overall site suitability was more related to their perception of visual characteristics rather than the actual condition. Actual measures indicate water bodies to be impaired biologically but from a recreation perspective the definition of being 303(d) listed does not have an effect on perceptions. The number of impairments also didn't have an impact on swimming, fishing, and boating suitability (Figure 9).

Sites rated between a score of 3.5-5 can be considered good for West Virginia tourism especially segments with all three activity types rated as excellent. River segments that are stocked were perceived as having the highest suitability rating for fishing compared to other activities with the exception of Upper Blackwater and Big Sandy Creek. The Blackwater and Big Sandy are known for their white waterreaches and both rate high in suitable boating activities. The "gray zone" designated river segments that are perceived as slightly impaired for recreation use (Figure 9). Why do river segments such as the Bluestone, North River, Three Forks Creek, and others lie within the "gray zone"? Are these river sites less popular for recreation compared to other sites due to accessibility or river quality? The Bluestone River is in the same relative location to the New River and both have reaches designated as national scenic rivers, but the New River has a higher mean suitability rating than the Bluestone. Bluestone is designated as impaired by PCB's but according to our study, PCB's were perceived as having better water quality than non-impaired sites but were perceived has being less suitable (Figure 8). The Right Fork of the Buckhannon River rated high in swimming and fishing activities but had a relatively low boatable rating. According to Americanwhitewater.org, Right Fork Buckhannon 
has class II and III+ rapids during normal flow. Changes in flow conditions have important consequences in recreation opportunity especially when boating (Kakoyannis \& Stankey, 2002). Flow regime is just one variable that could be affecting boat suitability.

If activities are rated differently within river segments, managers can identify specific stakeholders and manage based upon activity demand. Improvements can be made to benefit water recreation, increase economic opportunity and promote conservation and remediation effort. If water resource managers intend to "restore and maintain the chemical, physical, and biological integrity of the Nation's waters", it starts at the local level and can be initiated by increasing recreation opportunity and awareness of stream health by targeting users.

\section{Spatial Patterns of User Perceptions}

Brody et al., (2004) conducted one of the first studies using geographic information systems (GIS) analytical techniques to measure distance and location as it relates to environmental perceptions. Their findings suggest perceptions and beliefs about natural features are not randomly distributed but rather clustered across space (Brody et al., 2005). Perceptions of water quality among two watersheds were found to be clustered based upon social networks, proximity, location, and socio-demographic factors. It was suggested that the clustering was a result of community activism and involvement.

Both spatial autocorrelation and hotspot analysis are GIS analytical techniques that were used in determining spatial patterns and significant cluster occurrences as suggested by Brody et al. (2005). River segment level variables that were tested using the global Moran's I statistic were all considered random with the exception of fishing suitability and the fish 
composite score which were classified as having a dispersed distribution. None of the variables were clustered based upon river segments. The study findings by Brody et al. (2005) found a randomly selected sample of residents did not yield a randomly distributed pattern of results. We followed a stratified sampling design targeting watershed organizations which may have a different impact on the distribution pattern. In addition, Brody et al. (2005) had a large sample size of $n=1005$ and identified clusters by respondent. We identified clusters by mean perceptions per river segment with a sample size of $n=34$; this could be a reason for the existence of no pattern. A previous study asked the public to assess biodiversity within the Prince William Sound and found a high proportion of their sample perceiving biodiversity importance as a whole region rather than specified locations (Brown et al., 2004). Our study results suggest that respondents are not making generalizations about a particular region's water quality and water recreation suitability (i.e. the southern coal fields region is not being perceived as having poor water quality compared to other regions). Our small sample size should be emphasized and our results should be viewed as a preliminary conclusion. In order to determine if perceptions are clusters accurately, a larger random sample is needed.

\section{Summary and Conclusions}

Given our limited survey responses, this survey has provided an explorative approach to examining local perceptions based on two spatial scales (watershed \& river segment level). We propose an approach is needed in combining perceptions and bioassessments on a river segment scale for watershed management. Comparing rivers to each other was determined to be an effective way in prioritization of management actions and to locate patterns of recreation use on a state level. Local values especially when collected systematically can complement and 
strengthen biological assessments and incorporate stakeholder involvement. If public support is to be achieved, it is imperative to close the knowledge gap based on which nature conservation was initially founded, human values.

In result of this study, there was little to no relationship between recreational user perceptions and fishery assemblage data. Lewis (2010) found perceptions to be significantly different from bioassessment ratings. Perceived quality has been shown to differ significantly from actual quality and it could have the potential to cause conflict among managers and users (Mullens \& Bristow, 2003). A disconnect exists between perception and biological condition with respect to fishery data and impaired water bodies. The majority of impaired and not impaired river segments were in agreement on perceptions of water quality by activity. A total of five not impaired river segments were ranked as having poor water quality for all three activity types suggesting one of two things: impairment does not have an effect on perceived water quality or suggests perceptions are lagging behind current condition assuming that the biological data is correct. Perception data can determine if the gaps between perception and reality are due to a lack in public outreach or due to inaccurate scientific data.

West (1989) expressed a need in identifying user perceptions of water quality to recognize additional parameters that should be measured and that are meaningful to the users. West found many users do not perceive scientific based regulations to be valid and high levels of mercury, lead, and other heavy metals do not deter active users. A disconnect lies between what the scientific data reveals and what the user perceives. To effectively manage a resource, attempts must be made to incorporate the user perspective (West, 1989). 
Biological importance of a water body may be amplified with special place meanings that recognize the overall significance of an area (Brown et al., 2004). Local values are place specific and are embedded into our local environment. In our study, we were limited by our sample size, but we were able to provide baseline information on water recreationists by watershed and information regarding their perceptions of specific river segments. Watershed management should understand where and what type of recreation are being used. Successful management is most effective when those that have a stake in the outcome benefit from the appropriate management approach.

Stakeholder involvement and funding are key components to recovery (Benham et al., 2007). If two river segments are both considered impaired, the one with greater stakeholder involvement and greater fiscal resources should have greater recovery potential (Palmer et al., 2005; Benham et al., 2007). Norton (2009) suggests recreational use frequently provides a strong stimulus for community support of restoration or protection efforts. In a 1991 TMDL EPA report, guidance suggested that water body benefits and public support should be considered for priority setting, but it should only be considered when the degree of impairment or risk are acknowledged (EPA, 1991)

Impaired sites with high perceived suitability reveals that recreational values exists for impaired sites. The lower Tygart River, Cranberry River, lower Elk River, upper Blackwater River, lower Greenbrier River, South Branch Potomac River, and Big Sandy Creek were all perceived as having high site suitability across all activity types; they are also all listed as impaired on WV 303(d) list. Point being, there is a difference between impaired sites with high suitability and 
sites with low suitability like Decker's Creek and Lower Muddy Creek. Perceptions can separate segments with high value from those with little to no value in order to "flag" rivers in which to focus intervention efforts. As previously mentioned, sites with high stakeholder support provide greater recovery potential. Managers can improve areas of high suitability such as Big Sandy Creek or the lower Greenbrier to start meeting the requirements of TMDLs and begin the process of delisting.

Not impaired sites within the gray zone can also be further investigated to determine why those areas are good for one particular activity but not all three activity types. The Right Fork Buckhannon River was rated as excellent for swimming and fishing but considered slightly impaired for boating. Trail statistics from www.Trails.com claims the Right Fork Buckhannon has areas suitable for boating activity. In a study conducted by Pflüger et al. (2010) they found users to prefer high flows in small rivers and minimum bank exposure. The Right Fork Buckhannon is a small wadeable stream and is likely impacted by fluctuating flow. This may be the reason why survey respondents suggest boating is rated lower than other activities. Survey data identifies the variability in site importance and can be utilized as a tool in defining an initial starting point towards making clear management decisions about impairment and system specific efforts in obtaining TMDL and WQS requirements.

\section{Management Implications}

Our results suggest two actions to be taken for management of water resources in West Virginia. First, water recreationists can be used to incorporate local stakeholder support with the improvement, preservation, and restoration of valuable waterways. If management aims to 
benefit for the user, the user is likely to become more invested through increased participation and thus more willing to protect and restore river segments. Those who participate in outdoor recreation have influenced pro-environmental behaviors in terms of time and money donations to environmental groups (Cline \& Collins, 2003). Benefits for the user could help reinforce the notion and importance of West Virginia waters as a contribution to human well-being and can provide stakeholder support in restoration success.

Second, we believe that the use of perception data within the context of water resource management can be used to identify knowledge gaps between perceived and actual river condition. When perceptions match measured river condition, assessments become more valid to resource users. When the two sources are in disagreement, information from both sources needs to be reexamined on multiple spatial scales (Neis et al., 1999).

\section{Recommendations for Future Research}

The main limitations to this study were derived from the survey design. For further work, a mixed-mode survey approach should be used to reduce bias and coverage error (Dillman \& Tarnei, 1988; Schaefer \& Dillman, 1998). With rural populations such as those in West Virginia, it was difficult in making contact by internet only. A mixed-mode survey starts with the least expensive approach (email) progressively moving into more expensive survey methods, such as on-site surveys, to improve response rates (Schaefer \& Dillman, 1998).

With increasing demand and development of resource extraction, state and federal agencies need to focus on maintaining and restoring our waters in response to recreationists as consumers of ecosystem services. Future studies should look to accrue economic values of 
rivers and streams. Water recreation is considered a nonmarketable ecosystem service and can effectively influence adequate decision-making to plan, prioritize, and justify management objectives on a watershed scale. Changes with ecosystem services in either costs or benefits will have an impact on human well-being as it relates to nonmarketable goods and activities (Constanza et al., 1997). Without efforts to place a monetary value on an ecosystem service such as recreation, managerial and political decisions could potentially favor coal mining and other environmentally degrading practices by neglecting social interest and the significance of nonmarketable goods (Wilson \& Carpenter, 1999). 


\section{REFERENCES}

Anderson, A. (2013). Index of Biotic Integrity development for Wadeable West Virginia streams (Unpublished data)

Atkinson, R. \& Flint, J. (2001). Accessing Hidden and Hard-to-Reach Populations: Snowball Research Strategies. Social Research Update, Department of Sociology, University of Surrey, Guildford GU7 5XH, England. Issue 33

Benham, B., Zeckoski, R., \& Yagow, G. (2007). TMDL Implementation: Lessons Learned. Proceedings: Water Environment Federation TMDL 2007 Conference, Bellevue, Washington, pp. 428-442

Berkes, F., Colding, J., \& Folke, C. (Eds.). (2002). Navigating social-ecological systems: building resilience for complexity and change. Cambridge University Press.

Bonar, S. A., \& Hubert, W. A. (2002). Standard sampling of inland fish: benefits, challenges, and a call for action. Fisheries, 27(3), 10-16.

Brody, S.D., Highfield,W, \& Alston,L. (2004). Does Location Matter?: Measuring Environmental Perceptions of Creeks in Two San Antonio Watersheds. Environment and Behavior. 36:229-250

Brody, S.D., Highfield,W, \& Peck, B.M. (2005). Exploring the mosaic of perceptions for water quality across watersheds in San Antonio, Texas. Landscape and Urban Planning. 73: 200214.

Brown, G., Smith, C., Alessa, L., \& Kliskey, A. (2004). A comparison of perceptions of biological value with scientific assessment of biological importance. Applied Geography, 24(2), 161-180.

Burger, J., Sanchez, J., Gibbons, J. W., \& Gochfeld, M. (1998). Gender differences in recreational use, environmental attitudes, and perceptions of future land use at the Savannah River site. Environment and behavior, 30(4), 472-486.

Butler, L. T. \& Redfield,G.W. (1991). The Reston (Virginia) Lake-Use Survey: Public Perceptions and Management Implications. Water Resources Bulletin, American Water Resources Association. 27(4):603-610.

Chambers, R. (1980). The small farmer is a professional. Ceres, 13(2), 19-23.

Cline, S.A. \& Collins, A.R. (2003). Watershed Associations in West Virginia: Their impact on Environmental Protection. Journal of Environmental Management 67(4): 373-383

Collins, A., Rosenberger, R., \& Fletcher, J. (2005). The Economic Value of Stream Restoration. Water Resources Research, 41, W02017 
Copeland, C. (2006). Water Quality: Implementing the Clean Water Act. Congressional Research Service Reports. Paper 36. Updated Dec. 12, 2006, Order Code RL33466. http://digitalcommons.unl.edu/crsdocs/36

Cordell, H. K., Green, G. T., Betz, C. J., \& Planner, O. R. (2009). Long-Term National Trends in Outdoor Recreation Activity Participation---1980 to Now. Available online at warnell.forestry.uga.edu/ nrrt/nsre/IRISRec/IRISRec12rpt.pdf; last accessed February 17, 2013.

Costanza, R., d'Arge, R., de Groot, R., Farber, S., Grasso, M.,Hannon, B., Limburg, K. , Naeem, S. , O'Neill, R.V., Paruelo, J.,Raskin,R.G., Sutton, P., \& van den Belt, M. (1997). The Value of the World's Ecosystem Services and Natural Capital. Nature. 387, 253-260

Craik, K.H. \& Zube, E.H. (1976). Perceiving Environmental Quality: Research and Applications. Plenum Press, New York

Crawford, D. W. \& Godbey, G. (1987) Reconceptualizing barriers to family leisure. Leisure Sciences 9(2), 119-127.

Dahl, A.L. (1989). Traditional environmental knowledge and resource management in New Caledonia IUCN, World Conservation Union, Gland, Switzerland. In R.E. Johannes, (ed), Traditional ecological knowledge: A collection of essays. Pages 57-66

David, E. L. (1971), Public Perceptions of Water Quality, Water Resources.7(3), 453-457

Detenbeck, N.E. \& Cincotta,D.A. (2008). Comparability of a regional and state survey: effects on fish IBI assessment for West Virginia, USA. Hydrobiologia. 603: 279-300.

DeWalt, B. R., Pichón, F. J., Uquillas, J. E., \& Frechione, J. (1999). Combining indigenous and scientific knowledge to improve agriculture and natural resource management in Latin America. Traditional and modern natural resource management in Latin America., 101-121.

Dillman, D.A. \& Tarnai, J. (1988). Administrative Issues in Mixed Mode Surveys. In Telephone Survey Methodology, ed. Robert M. Groves, pp. 509-528. New York: Wiley.

Dinius, S. H. (1981). Public perceptions in water quality evaluation. JAWRA Journal of the American Water Resources Association, 17(1), 116-121.

Dogaru, D., Zobrist, J., Balteanu, D., Popescu, C., Sima, M., Amini, M., \& Yang, H. (2009). Community perception of water quality in a mining-affected area: A case study for the Certej catchment in the Apuseni mountains in Romania. Environmental management, 43(6), 1131-1145.

Doremus, H. (2006). Data Gaps in Natural Resource Management: Sniffing for Leaks Along the Information Pipeline. UC Davis Legal Studies Research Paper Series. Research Paper No. 83.

Duda, M. D. \& Nobile, J.L. (2010). The Fallacy of Online Surveys: No Data Are Better Than Bad Data. Human Dimensions of Wildlife, 15:55-64. 
Duram, L. A. \& Brown, K. G. (1999). Assessing Public Participation in U.S. Watershed Planning Initiatives. Insights and Applications, Society \& Natural Resources, 12: 455-467

Egan, K.J., Herriges, J.A., Kling, C.L., \& Downing, J.A. (2008). Valuing water quality as a function of water quality measures. American Journal of Agricultural Economics. 91(1)106-123

ESRI (2011). ArcGIS Desktop: Release 10. Redlands, CA: Environmental Systems Research Institute

Ferriss, A.L. (1963). Application of Recreation Surveys. American Association for Public Opinion Research. 27(3) 443-454.

Forster, B. A. (1989). Valuing outdoor recreational activity: A methodological survey. Journal of Leisure Research.

Fulton, D.C. \& Adelman, I.R. (2003). Social science (the human dimension) in fisheries. Fisheries 28(11):4

Goplerud III, C.P. (1995). Water pollution law: Milestones from the past and anticipation of the future. Natural Resources \& Environment. 10(7) pp. 8-12

Guijt, I. \& Sidersky, P. (1999). Matching participatory agricultural development with the social landscape of Northeast Brazil. In Fertile ground: The impacts of participatory watershed management. Ed. Hinchcliffe, F., Thompson, J., Pretty, J.N., Guijt, I., Shah, P. London, UK: Intermediate Technology Publications Ltd., 273-287

Hall, G. B., \& Close, C. H. (2007). Local knowledge assessment for a small-scale fishery using geographic information systems. Fisheries Research, 83(1), 11-22.

Hall-Arber, M., Pomeroy, C. \& Conway, F. (2009). Figuring out the human dimensions of fisheries: Illuminating models. Marine and Coastal Fisheries: Dynamics, Management, and Ecosystem Science. 1:300-314

Halvorson, W. L. (2005). Challenges to managing natural resource information. Notes.

Harrison, C., \& Burgess, J. (2000). Valuing nature in context: the contribution of common-good approaches. Biodiversity and Conservation, 9(8), 1115-1130.

Heckathorn, D. (2002). Respondent-Driven Sampling II: Deriving Valid Population Estimates from Chain -Referral Samples of Hidden Populations. Social Problems. 49(1,) 11-34

Hime, S., Bateman, I. J., Posen, P., \& Hutchins, M. (2009). A transferable water quality ladder for conveying use and ecological information within public surveys (No. 09-01). CSERGE working paper EDM.

Hitt, N.P. \& Angermeier, P.L. (2011). Fish Community and bioassessment responses to stream network position. Journal of the North American Benthological Society. 30(1), 296-309.

Hoyle, Z. (2009, September). The New Face of the South: Will Changing Demographics Affect How People View and Use Natural Resources. Compass, 14, 1-4 
$\mathrm{Hu}, \mathrm{Z}$. (2011). Water quality perceptions in the United States (Doctoral dissertation) Retrieved from Dissertations and Theses database. (UMI no. 3458277)

Hyman, E.L. (1981). The Uses, Validity, and Reliability of Perceived Environmental Quality Indicators. Social Indicators Research. (91) 85-110.

Johannes, R.E. (1978). Words of the lagoon: Fishing and marine law in the Palau district of Micronesia. University of California press, Berkeley, p. 245

Johnson, N., Ravnborg, H.M., Wstermann, O., \& Probst, K. (2002). User participation in watershed management and research. Water Policy. 4(6), 465-556

Kakoyannis, C. \& Stankey, G. H. (2002). Assessing and evaluating recreational uses of water resources: implications for an integrated management framework. Gen. Tech. Rep. PNW-GTR-536. Portland, OR: U.S. Department of Agriculture, Forest Service, Pacific Northwest Research Station. p. 59

Karr, J.R. (1981). Assessment of Biotic Integrity Using Fish Communities. Fisheries. 6(6),21-27

Karr, J.R., Fausch, K.D. ,Angermeier, P.L., Yant, P.R., \& Schlosser, I.J. (1986). Assessing Biological Integrity in Running Waters: A Method and its Rationale. Illinois History Survey Special Publication 5. 28

Keller, A.A. \& Cavallaro, L. (2008). Assessing the US Clean Water Act 303(d) listing process for determining impairment of a waterbody. Journal of Environmental Management 86: 699-711

Lewis, S.E. (2010). Perception vs. reality: stakeholder perception of and willingness to pay for watershed ecosystem integrity. (Doctoral dissertation). Retrieved from Dissertations and Theses database. (UMI no. 3421045)

Lipton, D. (2004). The value of improved water quality to Chesapeake Bay boaters. Marine Resource Economics, 19(2), 265-270.

Loomis, J., Kent, P., Strange, L., Fausch, K., \& Covich, A. (2000). Measuring the total economic value of restoring ecosystem services in an impaired river basin: results from a contingent valuation survey. Ecological Economics, 33(1), 103-117.

Mackinson, S., \& Nottestad, L. (1998). Points of view: combining local and scientific knowledge. Reviews in Fish Biology and Fisheries, 8(4), 481-490.

Mackinson, S. (2001). Integrating local and scientific knowledge: An example of fisheries science. Environmental Management. 27(4)533-545

Manning, R., 1999. Studies in Outdoor Recreation. Oregon State University Press, Corvallis.

Mehta, R. \& Sivadas, E. (1995). Comparing response rates and response content in mail versus electronic surveys. Journal of the Market Research Society. 4(37) 429-440 
McCormick, F.H., Hughes, R.M., Kaufmann, P.R., Peck, D.V., Stoddard, J.L., \& Herlihy, A.T. (2001). Development of an index of biotic integrity for the Mid-Atlantic Highlands Region. Transactions of the American Fisheries Society. 130:857-877

Mullens, J.B. \& Bristow,R.S. (2003). Overcoming the nation's best landscaped sewer: Recreators' perceptions of the Connecticut River. Journal of the American Water Resources Association. 39(1): 7-15

Muñoz-Carpena, R., Vellidis, G., Shirmohammadi, A., \& Wallender, W.W. (2006). Evaluation of modeling tools for TMDL development and implementation. American Society of Agricultural and Biological Engineers. 49(4): 961-965

Neis, B., Schneider, D. C., Felt, L., Haedrich, R. L., Fischer, J., \& Hutchings, J. A. (1999). Fisheries assessment: what can be learned from interviewing resource users?. Canadian Journal of Fisheries and Aquatic Sciences, 56(10), 1949-1963.

Nicolson, J.A., \& Mace, A.C., Jr. (1975). Water quality perception by users: Can it supplement objective water quality measures? Water Resources Bulletin, American Water Resources Association. 11(6): 1197-1207

Niemi, G. J. \& McDonald, M.E., (2004). Application of Ecological Indicators. Annual Review of Ecology, Evolution, and Systematics. (35):89-111

Norton, D.J., Wickham, J.D., Wade, T.G., Kunert, K., Thomas, J.V., \& Zeph, P. (2009). A Method for Comparative Analysis of Recovery Potential in Impaired Waters Restoration Planning. Environmental Management 44:356-368

Palmer, M. A., Bernhardt, E. S., Allan, J. D., Lake, P. S., Alexander, G., Brooks, S., ... \& Sudduth, E. (2005). Standards for ecologically successful river restoration. Journal of applied ecology, 42(2), 208217.

Pendleton, L. (2001). Exploring the Gap Between Measured and Perceived Quality. Los Angeles, Southern California Coastal Ocean Observing System, 29.

Pflüger, Y., Rackham, A., and Larned, S. (2010). The Aesthetic Value of River Flows: An Assessment of Flow Preferences for Large and Small Rivers. Landscape and Urban Planning, 95(1-2), 68-78.

Plafkin, J.L, Barbour, M.T., Porter, K.D., Gross, S.K., \& Hughes, R.M. (1989). Rapid Bioassessment Protocols for Use in Streams and Rivers: Benthic macroinvertebrates and fish. EPA/440/4-89-001 U.S. Environmental Protection Agency, Office of Water, Washington, D.C.

Pollock, K. H., Jones, C. M., \& Brown, T. L. (1994). Angler survey methods and their applications in fisheries management. American Fisheries Society. 
Richardson, R.B., Loomis, J. \& Weiler, S. (2006). Recreation as a Spatial Good: Distance Effects on Changes in Recreation Visitation and Benefits. The Review of Regional Studies. 36(3)362-380

Rhoades, R.E. (1998). Participatory watershed research and management- Where the shadows falls, International Institute for Environment and Development, Gatekeeper Series no. 81

Robertson, R. A., \& Colletti, J. P. (1994). Off-site impacts of soil erosion on recreation: the case of Lake Red Rock Reservoir in central lowa. Journal of soil and water conservation, 49(6), 576-581.

R Core Team (2013). R: A Language and Environment for Statistical Computing. R Foundation for Statistical Computing, Vienna, Austria. URL http://www.R-project.org

Rochet, M. J., Prigent, M., Bertrand, J. A., Carpentier, A., Coppin, F., Delpech, J. P., \& Trenkel, V. M. (2008). Ecosystem trends: evidence for agreement between fishers' perceptions and scientific information. ICES Journal of Marine Science: Journal du Conseil, 65(6), 1057-1068.

Sax, L. J., Gilmartin, S. K., \& Bryant, A. N. (2003). Assessing response rates and nonresponse bias in web and paper surveys. Research in Higher Education, 44(4), 409-432.

Schaefer, D.R. \& Dillman, D.A.(1998). Development of a standard email methodology: Results of an experiment. Public Opinion Quarterly. 3(62) 378-390

Sheehan, K.B. (2001). Email survey response rates: A review. Journal of Computer-Mediated Communication. 6:0.

Sheehan, K.B. \& Hoy, M.G. (1997). Email surveys: response patterns, process and potential. Proceedings of the 1997 Conference of the American Academy of Advertisers.

Sheehan, K.B. \& McMillan, S.J.(1999). Response variation in email surveys: An exploration. Journal of Advertising Research. 39(4) 45-54.

Silvano, R. A., \& Begossi, A. (2005). Local knowledge on a cosmopolitan fish: Ethnoecology of Pomatomus saltatrix (Pomatomidae) in Brazil and Australia. Fisheries Research, 71(1), 43-59.

Smeltzer, E. \& Heiskary, S. A. (1990). Analysis and Applications of Lake User Survey Data. Lake and Reservoir Management. 6(1): 109-118.

Smith, D. G., Cragg, A. M., \& Croker, G. F. (1991). Water clarity criteria for bathing waters based on user perception. Journal of environmental management, 33(3), 285-299.

Smith, D.B., Croker, G.F., \& McFarlane, K. (1995). Human Perception of Water Appearance 1. Clarity and Colour for Bathing and Aesthetics. New Zealand Journal of Marine and Freshwater Research. 29:29-43

Smith, D.B. \& Davies-Colley, R.J. (1992). Perception of Water Clarity and Colour in Terms of Suitability for Recreational Use. Journal of Environmental Management 36:225-235 
Soupir, C. A., Brown, M. L., Stone, C. C., \& Lott, J. P. (2006). Comparison of creel survey methods on Missouri River reservoirs. North American journal of fisheries management, 26(2), 338-350.

Stoddard, J. L., Herlihy, A.T., Hill, B.H., Hughes, R.M., Kaufmann, P. R., Klemm, D. J., Lazorchak, J.M., McCormick, F. H., Peck, D.V., Paulsen, S. G., Olsen, A. R., Larsen, D. P. , Van Sickle, J., \& Whittier, T. R. (2006). Mid-Atlantic Integrated Assessment: flowing waters report. EPA/620/R-06/001. Office of Research and Development, US Environmental Protection Agency, Washington, D.C.

Stringfellow, W.T. (2008). Ranking tributaries for setting remediation priorities in a TMDL context. Chemosphere 17: 1895-1908

Suplee, M.W., Watson, V., Teply, M. \& Mckee, H. (2009). How green is too green? Public opinions of what constitutes undesirable algae levels in streams. Journal of the American Water Resources Association (JAWRA) 45(1) 123-140

Tobias, T., 2000. Chief Kerry's Moose: A Guidebook to Land Use and Occupancy Mapping, Research Design and Data Collection. Union of British Columbian Indian Chiefs and Ecotrust Canada, Vancouver, BC.

United States Census Bureau (2010). West Virginia People QuickFacts. Retrieved from http://quickfacts.census.gov/qfd/states/54000.html

USEPA (1991). Guidance for water quality-based decisions: the TMDL process. Report EPA440/4-91-001. U.S. Environmental Protection Agency, Washington, DC. Available at: http://www.epa.gov/waterscience/library/wqstandards/

USEPA (2000). A Stream Condition Index for West Virginia Wadeable Streams. U.S. Environmental Protection Agency Region III, Environmental Services Division, and U.S. EPA Office of Science and Technology, Office of Water

USEPA Mid-Atlantic Water (2011). Mining Operations as Nonpoint Source Pollution. (Available at http://www.epa.gov/reg3wapd/nps/mining.html)

USEPA (2012). Fish and Aquatic Habitat: A survey of Inland States Residents. U.S. Environmental Protection Agency, Collection Strategies Division. OMB Control No. 2040-0283

Vaske, J.J. (2008). Survey Research and Analysis. State College, Pennsylvania. Venture Publishing, Inc.

Vaughan, W. J. (1986). The RFF water quality ladder. Mitchell, RC and RT Carson. The Use of Contingent Valuation Data for Benefit/Cost Analysis in Water Pollution Control, Final Report. Washington: Resources for the Future. Appendix B.

Verbeke, W., Sioen, I., Pieniak,Z., VanCamp, J. \& De Henauw, S. (2004). Consumer perception versus scientific evidence about health benefits and safety risks from fish consumption. Public Health Nutrition. 8(4) 422-429 
Viscusi, W.K., Huber, J. \& Bell, J. (2008). The economic value of water quality. Environmental and Resource Economics. 41(2)169-187

Walters, D.M. (2006). Development of a Fish Index of Biotic Integrity to Assess the Condition of West Virginia Streams: Technical Support Document. EPA/600/R-06/010. U.S. Environmental Protection Agency, Cincinnati, Ohio.

Wang, J. (2008). Development of Outdoor Recreation Resource Amenity Indices for West Virginia (Master's Thesis). Retrieved from Dissertations and Theses database. (UMI No. 9781248965573)

West, N. (1989). A preliminary review of water quality parameters and recreational user perceptions of nearshore water quality. Journal of Coastal Research. 5(3) 563-572

West Virginia Department of Commerce. (2013). SCORP 2009. Retrieved from http://www.wvcommerce.org/people/communityresources/applicationsanddownloads/ scorp.aspx

West Virginia Department of Environmental Protection. (2010). Integrated Water Quality Monitoring and Assessment Report. Division of Water and Waste Management

West Virginia Department of Environmental Protection. (2012). Integrated Water Quality Monitoring and Assessment Report (Draft). Division of Water and Waste Management.

West Virginia Department of Natural Resources. (2013). WV Fishing Regulations Summary.2013 [Pamphlet]. Retrieved from http://wvdnr.gov/fishing/Regs13/2013_Fishing_Regs.pdf

Wilson, Matthew A. \& Carpenter, S. R. (1999). Economic Valuation of Freshwater Ecosystem Services in the United States: 1971-1997. Ecological Applications, 9(3): 772-783

Yagow, G., Wilson, B., Srivastava, P., \& Obropta, C.C. (2006). Use of biological indicators in TMDL assessment and implementation. American Society of Agricultural and Biological Engineers. 49(4) 1023-1032 
APPENDIX A

CONSERVATIVE GAME ABUNDANCE SPECIES

\begin{tabular}{ll}
\hline Common Name & \multicolumn{1}{c}{ Scientific Name } \\
\hline Freshwater Drum & Aplodinotus grunniens \\
Northern Pike & Esox lucius \\
Muskellunge & Esox masquinongy \\
Chain Pickerel & Esox niger \\
Channel Catfish & Ictalurus punctatus \\
Redbreast Sunfish & Lepomis auritus \\
Bluegill & Lepomis macrochirus \\
Longear Sunfish & Lepomis megalotis \\
Smallmouth Bass & Micropterus dolomieu \\
Spotted Bass & Micropterus punctulatus \\
Largemouth Bass & Micropterus salmoides \\
White Perch & Morone americana \\
White Bass & Morone chrysops \\
Striped Bass & Morone saxatilis \\
Rainbow Trout & Oncorhynchs mykiss \\
Yellow Perch & Perca flacescens \\
White Crappie & Pomoxis annularis \\
Black Crappie & Pomoxis nigromaculatus \\
Flathead Catfish & Pylodictis olivaris \\
Brown Trout & Salmo trutta \\
Brook Trout & Salvelinus fontinalis \\
Sauger & Sander canadensis \\
Walleye & Sander vitreus \\
\hline
\end{tabular}


Appendix B

Survey Instrument 


\section{WestVirginiaUniversity}

Davis College of Agriculture, Natural Resources and Design

Coal River Survey 2012

WVU Graduate Research

Date $(\mathrm{mm} / \mathrm{dd})$ :

Introduction

This survey is being conducted by graduate student Jennie Franks of the Wildlife and Fisheries program at West Virginia University. The objective of this survey is to identify relationships between user perceptions and fishery assemblage data across watersheds around the state. Your opinions and attitudes regarding local watersheds are greatly valued. Results for this study may help establish priorities for river conservation in West Virginia. This survey is voluntary, anonymous, and no individual responses will be identified within published data.

There are a total of 23 questions in this survey and it should take about 10-15 minutes to complete. Please answer the following questions to the best of your ability. You do not have to answer every question in this survey. If you have any questions or concerns regarding the survey please feel free to contact Jennie Franks at jfranks1@mix.wvu.edu or at (309) 945-5593.

$=\mathrm{x}=\mathrm{=}=\mathrm{=}=\mathrm{=}=\mathrm{=}=\mathrm{=}=\mathrm{=}=\mathrm{=}=\mathrm{=}=$

1. What is your gender?

Male $\quad \square$ Female

2. What is your age?

3. Are you a resident of West Virginia?

$\square$ Yes $\quad \square$ No

4. If yes, how long have you been a resident of West Virginia?

$\square$ Whole Life

$\square+10$ years

$\square$ 5-9 years

$\square<5$ years

Within this survey water recreation is strictly defined by the three most common water-based recreation activities: fishing, swimming, and boating. Boating includes kayaking, canoeing, and rafting. 
5. Have you participated in fishing, swimming, or boating within the Coal River basin in the last 12 months?

\begin{tabular}{|c|ccc|}
\hline Fishing & $\square$ Yes & $\square$ No & $\square$ I don't know \\
\hline Swimming & $\square$ Yes & $\square$ No & $\square$ I don't know \\
\hline Boating & $\square$ Yes & $\square$ No & $\square$ I don't know \\
\hline
\end{tabular}

6. If you participated in any of these activities, how far did you travel to get to the Coal River basin? Miles

7. If you fish, swim, or boat at other sites besides those in the Coal River basin, how far (IN MILES) do you typically travel to participate in each activity?

Swimming: Miles traveled

Fishing: Miles traveled

Boating: Miles traveled

The following questions pertain to four different river sections in the Coal River watershed:

BIG COAL: From the city of Racine down to the confluence of Briar Creek

LITTLE COAL: From Waterways Park down to the Corridor G (hwy 119) bridge

POND FORK: From the city of Van down to the city of Madison in Boone County

LOWER SPRUCE FORK: From the Boone/Logan County line down to the mouth at the city of Madison

8. For the activities you participated in the last $\mathbf{1 2}$ months, rate (CIRCLE) their importance to you in these locations on a scale of 1-5, 1 being "most important", 2 being moderately important, 3 being least important, 4 being not at all important and 5 being I did not participate in this activity in the last 12 months.

Fishing Swimming Boating

\begin{tabular}{|l|lllll|llllll|llllll|}
\hline Big Coal & 1 & 2 & 3 & 4 & 5 & 1 & 2 & 3 & 4 & 5 & & 1 & 2 & 3 & 4 & 5 \\
\hline Little Coal & 1 & 2 & 3 & 4 & 5 & 1 & 2 & 3 & 4 & 5 & & 1 & 2 & 3 & 4 & 5 \\
\hline Pond Fork & 1 & 2 & 3 & 4 & 5 & 1 & 2 & 3 & 4 & 5 & & 1 & 2 & 3 & 4 & 5 \\
\hline Lower Spruce Fork & 1 & 2 & 3 & 4 & 5 & & 1 & 2 & 3 & 4 & 5 & & 1 & 2 & 3 & 4 & 5 \\
\hline
\end{tabular}


9. On average, how many days do you spend per year fishing, swimming, boating on the listed river $\operatorname{section}(\mathrm{s})$ ?

Big Coal

Little Coal

Pond Fork

Lower Spruce Fork
Fishing Swimming

Days

Days

Days

Days

Days

Days

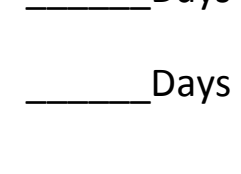

Boating

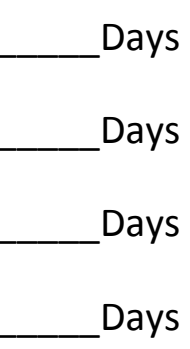

10. Are there any river sections that are unsuitable for recreational activities? Unsuitable meaning too shallow, too narrow, inaccessible, or other physical characteristics NOT related to water pollution. (Select the box that applies)

Fishing Swimming Boating

\begin{tabular}{|c|l|l|l|}
\hline Big Coal & $\square$ Suitable & $\square$ Suitable & $\square$ Suitable \\
& $\square$ Unsuitable & $\square$ Unsuitable & $\square$ Unsuitable \\
& $\square$ I don't know & $\square$ I don't know & $\square$ I don't know \\
\hline Little Coal & $\square$ Suitable & $\square$ Suitable & $\square$ Suitable \\
& $\square$ Unsuitable & $\square$ Unsuitable & $\square$ Unsuitable \\
& $\square$ I don't know & $\square$ I don't know & $\square$ I don't know \\
\hline Pond Fork & $\square$ Suitable & $\square$ Suitable & $\square$ Suitable \\
& $\square$ Unsuitable & $\square$ Unsuitable & $\square$ Unsuitable \\
& $\square$ I don't know & $\square$ I don't know & $\square$ I don't know \\
\hline Lower Spruce Fork & $\square$ Suitable & $\square$ Suitable & $\square$ Suitable \\
& $\square$ Unsuitable & $\square$ Unsuitable & $\square$ Unsuitable \\
& $\square$ I don't know & $\square$ I don't know & $\square$ I don't know \\
\hline
\end{tabular}

If unsuitable, please state why and please indicate which river section you are referring to if you answered unsuitable for multiple sections: 
11. For river sections where the activity is appropriate, please indicate how suitable the river water is for recreation use within the past year:

\section{Rating Descriptions}

1 Beautiful, could not be any nicer

2 Excellent

3 Slightly impaired because of the biological condition

4 Desire to fish, boat, or swim is substantially reduced because of the biological condition

$5 \quad$ Fishing, swimming, or boating are nearly impossible because of the biological condition

Fishing Swimming Boating

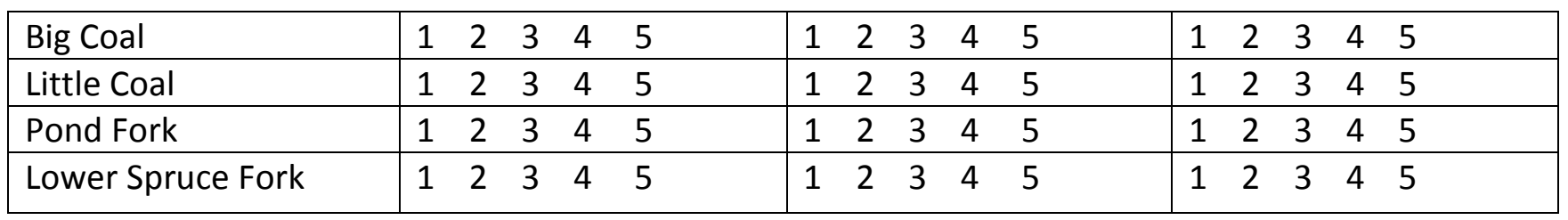

12. Please rank the environmental problems that you think most affect the river section(s) listed within the last 12 months. Select (CIRCLE) ONLY THE TOP THREE MOST IMPORTANT problems for each segment. Rank those top three from 1 being most important to 3 being least important.

Big Coal Little Coal Pond Fork Lower Spruce Fork

\begin{tabular}{|l|lll|lll|lll|rll|}
\hline Mine Drainage & 1 & 2 & 3 & 1 & 2 & 3 & 1 & 2 & 3 & 1 & 2 & 3 \\
\hline $\begin{array}{l}\text { Litter in and around the } \\
\text { waterbody }\end{array}$ & 1 & 2 & 3 & 1 & 2 & 3 & 1 & 2 & 3 & 1 & 2 & 3 \\
\hline Sewage pollution & 1 & 2 & 3 & 1 & 2 & 3 & 1 & 2 & 3 & 1 & 2 & 3 \\
\hline Bank erosion & 1 & 2 & 3 & 1 & 2 & 3 & 1 & 2 & 3 & 1 & 2 & 3 \\
\hline Acid precipitation & 1 & 2 & 3 & 1 & 2 & 3 & 1 & 2 & 3 & 1 & 2 & 3 \\
\hline Storm runoff & 1 & 2 & 3 & 1 & 2 & 3 & 1 & 2 & 3 & 1 & 2 & 3 \\
\hline Agricultural runoff & 1 & 2 & 3 & 1 & 2 & 3 & 1 & 2 & 3 & 1 & 2 & 3 \\
\hline $\begin{array}{l}\text { Flowback from fracking and } \\
\text { other drilling operations }\end{array}$ & 1 & 2 & 3 & 1 & 2 & 3 & 1 & 2 & 3 & 1 & 2 & 3 \\
\hline
\end{tabular}


13. Please rate the overall water quality of the following locations from poor to excellent:

Swimmable

Boatable

Fishable

\begin{tabular}{|c|l|l|l|}
\hline Big Coal & $\square$ Poor & $\square$ Poor & $\square$ Poor \\
& $\square$ Fair & $\square$ Fair & $\square$ Fair \\
& $\square$ Good & $\square$ Good & $\square$ Good \\
& $\square$ Very Good & $\square$ Very Good & $\square$ Very Good \\
& $\square$ Excellent & $\square$ Excellent & $\square$ Excellent \\
\hline Little Coal & $\square$ Poor & $\square$ Poor & $\square$ Poor \\
& $\square$ Fair & $\square$ Fair & $\square$ Fair \\
& $\square$ Good & $\square$ Good & $\square$ Good \\
& $\square$ Very Good & $\square$ Very Good & $\square$ Very Good \\
& $\square$ Excellent & $\square$ Excellent & $\square$ Excellent \\
\hline Pond Fork & $\square$ Poor & $\square$ Poor & $\square$ Poor \\
& $\square$ Fair & $\square$ Fair & $\square$ Fair \\
& $\square$ Good & $\square$ Good & $\square$ Good \\
& $\square$ Very Good & $\square$ Very Good & $\square$ Very Good \\
& $\square$ Excellent & $\square$ Excellent & $\square$ Excellent \\
\hline Lower Spruce Fork & $\square$ Poor & $\square$ Poor & $\square$ Poor \\
& $\square$ Fair & $\square$ Fair & $\square$ Fair \\
& $\square$ Good & $\square$ Good & $\square$ Good \\
& $\square$ Very Good & $\square$ Very Good & $\square$ Very Good \\
& $\square$ Excellent & $\square$ Excellent & $\square$ Excellent \\
\hline
\end{tabular}


14. If water quality were to be improved from the current level to the best possible level would you consider swimming, fishing, or boating more often, less often, or the same amount as you currently swim, fish, or boat? (Please check one box per cell)

Swimmable

Boatable

Fishable

\begin{tabular}{|c|c|c|c|}
\hline Big Coal & $\begin{array}{l}\square \text { More Often } \\
\square \text { Less Often } \\
\square \text { Same Amount } \\
\square \text { Currently at best } \\
\text { level } \\
\square \text { I don't know }\end{array}$ & $\begin{array}{l}\square \text { More Often } \\
\square \text { Less Often } \\
\square \text { Same Amount } \\
\square \text { Currently at best } \\
\text { level } \\
\square \text { I don't know }\end{array}$ & $\begin{array}{l}\square \text { More Often } \\
\square \text { Less Often } \\
\square \text { Same Amount } \\
\square \text { Currently at best } \\
\text { level } \\
\square \text { I don't know }\end{array}$ \\
\hline Little Coal & $\begin{array}{l}\square \text { More Often } \\
\square \text { Less Often } \\
\square \text { Same Amount } \\
\square \text { Currently at best } \\
\text { level } \\
\square \text { I don't know }\end{array}$ & $\begin{array}{l}\square \text { More Often } \\
\square \text { Less Often } \\
\square \text { Same Amount } \\
\square \text { Currently at best } \\
\text { level } \\
\square \text { I don't know }\end{array}$ & $\begin{array}{l}\square \text { More Often } \\
\square \text { Less Often } \\
\square \text { Same Amount } \\
\square \text { Currently at best } \\
\text { level } \\
\square \text { I don't know }\end{array}$ \\
\hline Pond Fork & $\begin{array}{l}\square \text { More Often } \\
\square \text { Less Often } \\
\square \text { Same Amount } \\
\square \text { Currently at best } \\
\text { level } \\
\square \text { I don't know }\end{array}$ & $\begin{array}{l}\square \text { More Often } \\
\square \text { Less Often } \\
\square \text { Same Amount } \\
\square \text { Currently at best } \\
\text { level } \\
\square \text { I don't know }\end{array}$ & $\begin{array}{l}\square \text { More Often } \\
\square \text { Less Often } \\
\square \text { Same Amount } \\
\square \text { Currently at best } \\
\text { level } \\
\square \text { I don't know }\end{array}$ \\
\hline Lower Spruce Fork & $\begin{array}{l}\square \text { More Often } \\
\square \text { Less Often } \\
\square \text { Same Amount } \\
\square \text { Currently at best } \\
\text { level } \\
\square \text { I don't know }\end{array}$ & $\begin{array}{l}\square \text { More Often } \\
\square \text { Less Often } \\
\square \text { Same Amount } \\
\square \text { Currently at best } \\
\text { level } \\
\square \text { I don't know }\end{array}$ & $\begin{array}{l}\square \text { More Often } \\
\square \text { Less Often } \\
\square \text { Same Amount } \\
\square \text { Currently at best } \\
\text { level } \\
\square \text { I don't know }\end{array}$ \\
\hline
\end{tabular}

15. Have you fished any of the listed river section(s) in the last two years?

$\square$ Yes $\quad \square$ No

If no, please skip to question 20

16. If yes, which section(s) do you fish (Please select all that apply)
Big Coal
$\square$ Little Coal
$\square$ Pond Fork
$\square$ Lower Spruce Fork 
17. What species do you catch when fishing in these river section(s)?

18. How many fish do you catch on a typical fishing day? \# Caught Fish

19. Do you practice catch and release as it pertains to these river section(s)?

\begin{tabular}{|c|l|}
\hline Big Coal & $\square$ Always \\
& $\square$ Sometimes \\
& $\square$ Never \\
& $\square$ Have not fished this section \\
\hline Little Coal & $\square$ Always \\
& $\square$ Sometimes \\
& $\square$ Never \\
& $\square$ Have not fished this section \\
\hline Pond Fork & $\square$ Always \\
& $\square$ Sometimes \\
& $\square$ Never \\
& $\square$ Have not fished this section \\
& $\square$ Always \\
& $\square$ Sometimes \\
& $\square$ Never \\
& $\square$ Have not fished this section \\
\hline Lower Spruce Fork &
\end{tabular}

\begin{tabular}{|c|l|}
\hline Big Coal & $\square$ Always \\
& $\square$ Sometimes \\
& $\square$ Never \\
& $\square$ Have not fished this section \\
\hline Little Coal & $\square$ Always \\
& $\square$ Sometimes \\
& $\square$ Never \\
& $\square$ Have not fished this section \\
\hline Pond Fork & $\square$ Always \\
& $\square$ Sometimes \\
& $\square$ Never \\
& $\square$ Have not fished this section \\
\hline Lower Spruce Fork & $\square$ Always \\
& $\square$ Sometimes \\
\hline
\end{tabular}


20. Do you consume recreationally caught fish in the listed river section(s)?

If no, then why? Please state which river section you are referring to if you answered no to multiple sections.

21. Do you consider the fish to be healthy to eat? Please place a check under the column that best describes how strongly you agree or disagree with each of the following statements. (check one box for each question)

\begin{tabular}{|l|l|l|l|l|l|l|}
\hline & $\begin{array}{l}\text { Strongly } \\
\text { Disagree }\end{array}$ & Disagree & Neutral & Agree & $\begin{array}{l}\text { Strongly } \\
\text { Agree }\end{array}$ & $\begin{array}{l}\text { I Don't } \\
\text { Know }\end{array}$ \\
\hline Big Coal & & & & & & \\
\hline Little Coal & & & & & & \\
\hline Pond Fork & & & & & & \\
\hline $\begin{array}{l}\text { Lower } \\
\text { Spruce Fork }\end{array}$ & & & & & & \\
\hline
\end{tabular}

22. Do you belong to a watershed organization or a water-based environmental group?

$\square$ Yes $\quad \square$ No

If yes, what group(s)?

23. Thank you very much for your response! If you have any comment or concerns please feel free to add them here: 
